NEURON-MICROGLIA INTERACTIONS IN MOTOR NEURON

DEGENERATION. THE INFLAMMATORY HYPOTHESIS IN AMYOTROPHIC

LATERAL SCLEROSIS REVISITED

Manuel J Rodríguez, Nicole Mahy

Department of Biomedical Sciences, Institute of Neuroscience, Institut d'investigacions Biomèdiques August Pi i Sunyer (IDIBAPS), Universitat de Barcelona and Centro de Investigación Biomédica en Red sobre Enfermedades Neurodegenerativas (CIBERNED). Barcelona, Spain.

Author for correspondence: Dr. Manuel J Rodríguez

Unitat de Bioquímica i Biologia Molecular

Facultat de Medicina, UB

c/ Casanova 143

E-08036 Barcelona, SPAIN

Phone: +34 934020586

FAX: + 34934035882

e-mail: marodriguez@ub.edu

Running title: Neuroinflammation in ALS 


\title{
NEURON-MICROGLIA INTERACTIONS IN MOTOR NEURON DEGENERATION. THE INFLAMMATORY HYPOTHESIS IN AMYOTROPHIC LATERAL SCLEROSIS REVISITED
}

\begin{abstract}
Research into the pathogenesis of amyotrophic lateral sclerosis (ALS) has obtained notable gene discoveries, although, to date, only progress with regard to treatment has been very modest. Currently ALS is considered a multifactorial disease that presents diverse clinical presentations, ranging from a monogenic inherited disease to an autoimmune pathology, and develops with misfolded protein aggregation and neuroinflammation. An important factor related to ALS pathogenesis is the microglial activation associated with degenerative motor neurons. This activation leads to changes in the expression of a wide range of genes related to phagocytosis and inflammation, and to profound modifications in the dynamic interactions between neurons and glial cells. Overactivation and deregulation of microglial activity causes deleterious effects and leads to neuronal death. However, the involvement of microglia in noninflammatory functions challenges our concept of neuroinflammation and opens up new possibilities for the study of the pathophysiological mechanisms of ALS. In this review we summarize the current knowledge on the adaptive interactions between neurons and microglia in ALS. We also discuss the hypothesis that controlling the extent of microglial activation and neuroinflammation may have clinical and therapeutic benefits for the condition.
\end{abstract}

KEYWORDS: Amyotrophic lateral sclerosis, motor neuron disease, neuroinflammation, microglia, astroglia, neuron-glia interaction. 


\section{INTRODUCTION}

Amyotrophic lateral sclerosis (ALS) is the most common adult motor neuron disease. Known in the US as Lou Gehrig's disease, after the legendary American baseball first baseman (1903-1941). ALS progresses rapidly and is invariably fatal. ALS afflicts some 350,000 people a year worldwide, with a prevalence of $2-4$ per 100,000 individuals. Before the age of 65 , slightly more men than women develop ALS, with the only striking female predominance appearing in bulbar-onset patients. This sex difference disappears after age 70 [1-3]. There is no curative treatment, and the drugs currently available have an imperceptible action on the clinical course [4].

ALS was described for the first time 140 years ago [5]. Despite the identification of several single gene mutations with more than 10 loci, mostly in autosomal dominant familial cases (fALS), ALS is a multisystem neurodegenerative disease whose origin and progression are not clearly understood [6]. For the familial forms, fifteen years after the initial discovery of mutations in the enzyme $\mathrm{Cu} / \mathrm{Zn}$ superoxide dismutase (SOD1), a diversity of new genetic mutations have been progressively identified, including TAR DNA binding protein-43 (gene TARDBP, protein TDP-43) and the C9orf72 gene, until now the most common mutation underlying fALS. Recent data from family histories suggest a continuum of heritability between fALS and sporadic ALS (sALS), with a progressive decrease in the frequency of mutations in ALS genes $[7,8]$.

Except for the rare juvenile form (especially the very aggressive fused in sarcoma (FUS) gene mutation form [9]) the age range for developing ALS is quite broad, between 45 and 60 years [10]. The progressive atrophy and loss of upper (corticospinal) and lower (spinal and bulbar) specialized neurons lead to muscle atrophy, weakness and spasticity, and rapidly to paralysis [11]. In a diversity of phenotypes, the extrapyramidal, cerebellar, sensory or autonomic systems are also affected [12]. (See 
the ALS Research Forum webpage [13] for detailed information). The approximately 20 per cent of ALS patients who develop frontotemporal dementia (FTD), adds another dimension the disease's genetic and phenotypic variability [14-17]. Together with its large clinical heterogeneity (Figure 1a) even within the familiar forms [18-20] the absence of specific biomarkers delays ALS diagnosis and strongly limits an early neuronal therapeutic approach.

Until now, the higher ALS prevalence in specific groups of patients (football players [21-23], veterans of the Gulf War [24,25] or farmers with elevated pesticide and/or fertilizer exposure [26-29]) has not helped unravel the cascade of events or the driving force underlying the disease. Several pathological mechanisms such as genetic factors, environment, autoimmunity, oxidative stress, excitotoxicity, microglial activation, impairment in filament organization and neuronal transport, and misfolded proteins have been proposed as possible explanations of ALS heterogeneity [30,31]. Among them, misfolded protein aggregation and neuroinflammation are the only common mechanisms present in most ALS patients (Figure 1b). The recent implication of microglia in non-inflammatory functions challenges our concept of neuroinflammation and opens up new avenues in the study of ALS pathophysiology. In this review we discuss the current knowledge of these mechanisms, placing special emphasis on the non-inflammatory dynamic interactions between neurons and microglia in ALS.

\section{GENETICS OF ALS}

The hunting for genetic mutations causative for ALS has accumulated substantial body of research, with a wide range of results. According to the ALSoD database [32], 126 genes had been associated with ALS by September 2015. Of these, defects in six genes have been found to be main causes of the disease [33], and a growing number of genes 
such as the fractalkine receptor (CX3CR1), UNC13A, KIFAP3, EPHA4 and SLC11A2 have been associated with ALS susceptibility, progression or prevalence. [34-38] (Table 1) Multiple mutations of a sole gene also lead to graded phenotypic affectations. For example, the 166 widely dispersed exonic mutations of the $\mathrm{Cu} / \mathrm{Zn}$ superoxide dismutase (SOD1) gene coding for a mitochondrial enzyme of only 153 amino acids that neutralize toxic superoxide radicals are associated with some $20 \%$ of fALS and 1$3 \%$ of sALS, all characterized by a large heterogeneity in their presentation [39-43].

However, toxicity of SOD1 exon mutations is related not to altered enzyme activity but to the formation of SOD1 misfolded protein aggregates [44-47]. Characterized in motor neurons and glial cells, wild-type and mutant SOD1 aggregates $[39,48]$ correlate with a similar ALS phenotype $[49,50]$ and also in mice with wild-type SOD1 causing ALS [51]. Inflammation and neuronal death represent a cascade events that are also present in other neurodegenerative diseases characterized by misfolded protein aggregates like the protease-resistant prion protein, Amyloid- $\beta$, Tau, or $\alpha$-synuclein $[52,53]$.

This toxic formation of protein aggregates applies to many other native and mutated misfolded proteins characterized in ALS patients, like the vesicle associated membrane protein (VAMP)-associated protein (VAPB), TARDBP, FUS, and angiotensin (ANG) genes $[33,54]$, and has been extended by the discovery of frequent combined C9orf72 gene mutations that facilitate native protein aggregation (see below). The recently discovered TBK1 gene mutations modify two main pathways, inflammation and autophagy [55], and may alter microglial adaptation to neuronal damage, in particular the engulfment of dying spinal cord neurons [56].

Different VAPB mutations combined with other ALS-relevant mutations, like those in C9orf72 [57,58], have been identified in fALS patients. The formation of mutant VAPB cytoplasmic aggregates triggers $\mathrm{Ca}^{2+}$ dependent aberrant functioning of the endoplasmic 
reticulum (ER) and Golgi apparatus. This also occurs in surrounding cells in which wild-type VAPB aggregation takes place, leading to motor neuron degeneration $[59,60]$. The recent discovery in patients with and without fALS history that the C9orf72 gene defect can cause ALS $[61,62]$ has added a new dimension to the disease's complexity. It challemged the present fALS and sALS classification (Figure 1b), and offered a convergent explanation of ALS pathogenesis that includes RNA dys-metabolism and proteinopathy [63]. In fact, the common genetic variations found in both genetic and sporadic ALS patients by genome-wide association studies [64,65] include a diversity of factors that support ALS susceptibility and heterogeneity, and argue for subgroups of both fALS and sALS along an ALS continuum.

\section{ALS AS A MISFOLDED PROTEIN DISEASE}

The genetic data suggest that alterations in RNA processing (modified protein synthesis) and proteinopathy (modified protein degradation) are key to both fALS and sALS pathogenesis. For example, $97 \%$ of all sporadic cases present TDP-43 proteinopathy, characterized by cytoplasmic TDP-43 ubiquitinated aggregates [66]. In $45 \%$ of all sporadic FTD cases, and in numerous genetic mutations of fALS-FTD, TDP43 proteinopathy also occurs [16,67]. Multiple forms of ALS may then be viewed as different manifestations of a misfolded protein disease (MPD), in which a misfolded protein like SOD1, VAPB or TDP-43 develops insidiously and initiates an early neurodegenerative process that manifests clinically in middle or late life in both sALS and fALS.

In all MPDs, the pathogenic mechanism represents the initial aggregation and CNS deposition of a misfolded protein in specific neurons and/or astroglia that grow following a crystallization-like process [68-70]. Many of these proteins are 
metalloproteins in which the ionized metal participates directly in the protein conformation and function. Besides the mutation hotspots of the coding genes identified in fALS and sALS and associated with a proteinopathy, the age-related metal dyshomeostasis allows variations of metalloprotein conformation and activity that may also result in intracellular aggregates. For example, the variety of binding affinities and binding sites reported for copper to SOD1 indicate that, through these numerous possible interactions, the copper level may directly drive the diversity of the states and functions of these proteins, in particular in an insoluble state [71]. This possibility may pave the way for new therapeutic strategies able to control the misfolded protein metal dyshomeostasis (see below).

Elaborate systems have evolved to protect cells from misfolded proteins. An example is the ubiquitin-proteasome system, which degrades the newly translated proteins that failed to fold correctly [72,73]. In PMD, misfolded proteins are not removed and they aggregate within the cell. As seen in the frontal cortex and spinal cord from sALS patients and in the $\mathrm{SOD} 1^{\mathrm{G} 93 \mathrm{~A}}$ spinal cord in mice, these aberrant intracellular accumulations result in ER stress, proteasomal impairment and increased energy demand, progressive Golgi damage, and mitochondrial dysfunction with massive oxidative stress $[53,74-76]$. In addition, these aggregates from dying neurons/astrocytes or mediated by exosomes activate a microglial phagocyte phenotype to remove aggregates and cellular debris [77,78] (figure 2) and extends the damage to the surrounding cells mostly via $\alpha$-amino-3-hydroxy-5-methyl-4-isoxazolepropionic acid (AMPA) receptor-mediated excitotoxicity in spinal motor neurons [79]. Similar results are observed with the Guam population diet which is rich in $\beta$-methyl-amino-L-alanine (BMAA). It chronically activates AMPA receptors, and in combination with other insults or with genetic predisposition, leads to ALS [80,81]. 
Glia participation in the neurodegenerative process depends on increased energy consumption [82,83]. Increased energy consumption is also required for neurons to engulf aggregates, repair damage or enter in apoptosis [84-86]. In these conditions, glucose transport to CNS is not sufficient to cover demand, and lactate is formed within astrocytes and sent to neurons for its complete oxidation [87,88]. As a result, the tissue $\mathrm{pH}$ decreases, which alters protein folding and induces aggregate formation, as observed with Amyloid- $\beta$ [89]. In ALS, this dynamic adaptation of the glial phenotype to the graded metabolic and structural modifications results in an overproduction of neurotoxic molecules and chronic neuroinflammation (Figure 2) which drives, at least in part, the disease progression [77,90-92] .

The pleiotropy of the ALS genes coding for proteins involved in this pathogenic process represents, in fact, a convergent mechanism that helps explain the broad spectrum and peculiar complexity of ALS clinical manifestations [93]. The presence of alterations in interrelated metabolic pathways has also been confirmed by blood analysis of ALS patients [94]. Currently, there is a growing consensus among clinicians and researchers that the degeneration and death of upper and lower motor neurons relies on the convergence of various altered metabolic processes in which neuroinflammation is always present and related with high energy consumption and misfolded protein formation (Figure 1b). For these reasons, energy metabolism and nutritional status are factors that help to explain the penetrance variability of ALS genes $[95,96]$

\section{ENERGY METABOLISM AND NUTRITION IN ALS}

Whole body energy metabolism is impaired in ALS, and body mass index and overall nutritional status at disease onset are independent predictors of survival in ALS [94]. A recent metabolomics study identified alterations characteristic of an increased glycolysis 
and lipolysis in order to produce more adenosine triphosphate (ATP) and thus to facilitate energy consuming processes [97]. This overall increase in energy demand reflects major cellular activity in an atempt to control the ALS neurodegenerative process taking place and to activate CNS and muscle repair. To ensure very high levels of ATP production from carbohydrate and lipid oxidation, mitochondria increase their activity and number, resulting in enhanced release of reactive oxygen species (ROS) [98]. In close contact with the nucleus, which also produces ATP from the ADP-ribosyl residues after sudden extensive changes in chromatin [99] (perhaps the ones caused by the heterogeneous ribonucleoproteins (hnRNPs) identified in ALS) proteasome becomes especially important for maintaining cellular homeostasis through degradation of ubiquitinated factors like Drp1, which control mitochondria fusion and fission and the ubiquitinated misfolded ALS proteins [100]. In addition, reduced glucose uptake and metabolism consequent to increased glucocorticoid signaling pathways cannot be discarded [101-103].

In fact, the on-going ALS neurodegenerative process is the result of two dynamic tissue mechanisms, one neurotoxic and an adaptive neuroprotective. The high-energy demand present in ALS must be part of this second mechanism, which remains efficient despite its elevated ROS production and progressive mitochondria and proteasome damage, and the altered ER-mitochondria interactions. In any case, the importance of rich-energy nutrition must be considered a key aspect of the patient care. In this framework, the Guam population, whose etiology of ALS correlates significantly with picking, processing, and eating cycad seed flour rich in neurotoxins such as BMAA, a potent glutamate agonist at both AMPA and kainate receptors [104] exemplifies the relevance of nutritional factors $[105,106]$. As such recent clinical trials have highlighted the importance of controlling ALS patient nutrition, with interventions from 
complementary approaches (ClinicalTrials.gov identifier: NCT00983983) or with administration of olanzapine, a weight gain drug (ClinicalTrials.gov identifier: NCT00876772).

\section{REFINING CONTROL OF NEUROINFLAMMATION IN ALS}

Until a few years ago, little was known about microglia adaptation and participation in ALS, and the microglia's direct and permanent involvement in the disease is a recent discovery. ALS pathophysiology includes a chronic microglial reaction in the surroundings of degenerative motor neurons [107]. In patients with ALS, microgliosis appears specifically in the motor cortex, along the corticospinal tract, and in the ventral horn of the spinal cord [108-110]. Although the molecular mechanisms of this neuroinflammation have not been clarified, it has been demonstrated that activation of microglia in the ALS-injured CNS leads to release of cytokines, chemokines, and neurotrophic or neurotoxic factors that stimulate astrocytes and mobilize cells from the peripheral immune system [111-113]. These cells in turn produce new cytokines creating a chronic inflammatory response [111,112].

In the healthy CNS, microglia present a highly ramified morphology, express receptors for neurotransmitters and neuromodulators [116-118], dynamically monitor the neuronal microenvironment and actively respond to neuronal activity as an integrated part of the "quad-partite" synapse [119-121]. This non-inflammatory microglial activity has important roles in CNS development eliminating the excess of neurons and controlling synaptic pruning and maturation of excitatory synapses (see [122] for a review). In the adult brain, the microglia is an important player in the regulation of synaptic plasticity $[121,123,124]$ and in clearing newborn adult hippocampal progenitors [125]. Thus, there is evidence of the involvement of microglia in the control 
of long-term potentiation [126-128] long-term depression [129], synaptogenesis $[130,131]$, and in sensing and eliminating defunct synapses [119].

These non-inflammatory roles of microglia involve dynamic interactions with neurons. Microglia are maintained in surveillance via signaling between fractalkine (CX3CL1) and its G-coupled protein receptor, CX3CR1. In the CNS, fractalkine is expressed by neurons as a membrane-bound glycoprotein, from which a soluble chemokine can be proteolytically released [132,133]. Fractalkine modulates migration, motility, and activation of microglia by interaction with the CX3CR1, which is specifically expressed in microglia [112]. In turn, the interaction fractalkine-CX3CR1 is required for proper maturation of excitatory synaptic transmission [134]; mice lacking CX3CR1 show persistent alterations in hippocampal glutamatergic transmission [135].

When microglia become reactive, their morphology changes, ranging from enlargement of processes and hypertrophy of the cell body to acquisition of an amoeboid shape. Besides these morphological alterations, reactive microglia also release cytokines and upregulate a variety of surface molecules[113,136-138]. Classically, microglia have been considered as resident macrophages of the CNS and the concept of macrophage polarization has been extrapolated to explain reactive microglia activity [139]. According to this paradigm, M1 (or classically activated) microglia present inflammatory activity, whereas M2 (or alternatively activated) microglia have tissue repair functions [107]. Initially a pro-inflammatory M1 phenotype aims to protect and repair damaged tissue but prolonged and excessive inflammation is cytotoxic and induces neuronal death [136-138]. Pro-inflammatory microglia promote a neurotoxic Tcell response and are cytotoxic owing to the secretion of nitric oxide (NO) and classical pro-inflammatory cytokines such as interleukin (IL)-1 $\beta$, IL-6, and tumor necrosis factor (TNF)- $\alpha$, ROS production and the reduction of protective trophic factor expression 
[142]. In addition, chronically activated microglia may become increasingly dysfunctional and may directly participate in the development of secondary tissue injury [143]. In contrast, M2 neurorestorative microglia activity includes the production of high levels of anti-inflammatory cytokines like IL-4, IL-10, neurotrophic factors, and proteins such as insulin-like growth factor (IGF)-1, arginase-1 and Ym-1 [144-146].

However, the M1 vs. M2 paradigm of macrophage activity has recently been reappraised since it appears to be at odds with the recent data emerging from epigenetics and genome-wide transcriptional studies [112,147]. New findings have also established that microglia are a unique cell population, distinct from macrophages $[112,148]$. Analysis of acutely isolated microglia from $\mathrm{SOD} 1^{\mathrm{G} 93 \mathrm{~A}} \mathrm{tg}$ mice revealed upregulation of both neuroprotective and toxic factors related with ALS [112]. SOD1 ${ }^{\mathrm{G} 93 \mathrm{~A}}$ microglia upregulated the expression of IGF-1 and progranulin, two microglial factors known to confer neuroprotection and increase survival in ALS models $[149,150]$, and progranulin mutations are major known genetic causes of ALSFTD [151]. With respect to the neurotoxic factors, metalloproteinase 12 and optineurin are upregulated in $\mathrm{SOD} 1^{\mathrm{G} 93 \mathrm{~A}}$ microglia [112]. Mutations in optineurin cause fALS $[152,153]$ and deregulate interferon signaling [154], while metalloproteinase inhibition increases survival in ALS mice [155]. More interestingly, in the same study SOD $1{ }^{\mathrm{G} 93 \mathrm{~A}}$ microglia also increased the expression of genes related with Alzheimer's, Huntington and Parkinson's diseases but not of genes related with lipopolysaccharide-induced microglial activation [112].

Thus, the M1-M2 dichotomy does not seem the best-suited concept for explaining the microglial response to motor neuron injury. Rather, microglia become reactive through expression changes in a wide range of genes that mediate the acquisition of new cell functions. This means that, at each moment, the balance of secreted molecules from the 
microenvironment determines a spectrum of microglial phenotypes that also vary with the time and intensity of neuron damage $[112,145]$. However these phenotypes are classified, microglia respond with a large diversity of signals, some of them detrimental and others restorative, which modulate neuroinflammation and thus interfere with ALS progression (Figure 3).

Astrocytes also participate in the inflammatory mechanisms associated with motor neuron degeneration [156-158] and may play a dual role. Like microglia, astrocytes exert both toxic and protective effects on neurons in a context-dependent manner (Figure 3). In fact, they may represent a diverse population of genetically tractable cells that mediate neural circuit-specific roles in health and disease (see [159] for a review). Astrocyte activation has been described in the spinal cord, motor cortex and subcortical white matter $[160,161]$ of ALS patients. In the SOD $1^{\mathrm{G} 93 \mathrm{~A}}$ tg mouse, astrogliosis is concomitant with motor neuron loss $[161,162]$.

Astrocytes express MHC molecules and can present antigens to primed memory $\mathrm{T}$ cells [163]. They respond to neuronal injury by releasing acute-phase proteins such as $\alpha 1-$ antichymotrypsin and $\alpha 2$-macroglobulin, complement proteins, and neuronal growth factors and cytokines [116]. In general, their neurotoxic activity is mediated via activation of pattern recognition receptors such as Toll-like receptors. After receptor activation, astrocytes secrete cytokines like CCL2, IL-6 and other neurotoxic factors that enhance the inflammatory response $[108,164,165]$. Their neuroprotective effects are mediated by an homeostatic control of neuronal activity $[159,166]$ and the release of neurotrophic factors such as nerve growth factor and IGF-1 [165].

Astroglia also contribute to motor neuron degeneration through non-immune mechanisms that may be associated with abnormal astrocyte activity rather than with astrogliosis. For example, in ALS patients and in ALS animal models, astroglia lead to 
glutamate excitotoxicity due to a decreased expression of glutamate transporter-1 [167,168]. A recent study has related the increased expression of connexin 43 in the motor cortex and spinal cord of ALS patients, and enhanced gap junction coupling in SOD1 ${ }^{\mathrm{G} 93 \mathrm{~A}}$ mice, with the course of the disease [169]. The subsequent increased hemi channel-mediated activity and elevated intracellular calcium levels suggest excessive astrocyte exchange of metabolites, ions and second messengers, which results in an astrocyte-mediated toxic effect on motor neurons.

\section{IS ALS A NEUROINFLAMMATORY DISEASE?}

Research into the pathogenesis of ALS had conventionally assumed that neuroinflammation was a response to motor neuron injury and extracellular protein deposition. However, studies in SOD1 tg mice evidenced microglial activation even before motor neuron cell death $[170,171]$, which suggested the hypothesis that neuroinflammation might contribute to ALS pathogenesis [107]. Currently, there is increasing evidence linking ALS molecular hallmarks with modifications in microglial activity or the immune system response. For example, TDP-43 and the p65 subunit of the nuclear factor- $\kappa \mathrm{B}(\mathrm{NF}-\kappa \mathrm{B})$ are increased in the spinal cord of sALS patients when compared with healthy individuals [172]. TDP-43 interacts and co-localizes with p65 in microglia and neurons from ALS patients and mice expressing wild-type and mutant TDP-43 transgenes, but not in cells from healthy individuals or non-transgenic mice $[172,173]$. Thus, TDP-43 acts as a co-activator of $\mathrm{p} 65$, and microglia expressing larger amounts of TDP-43 produced more pro-inflammatory cytokines and neurotoxic mediators after activation [173]. At the functional level, inhibition of NF- $\kappa$ B activity in TDP-43 mice reduces denervation in the neuromuscular junction and ALS disease 
symptoms [174]. TDP-43 deregulation thus contributes to ALS pathogenesis, in part by promoting the inflammatory activity of the microglia.

Similarly, C9orf72 plays a key role in innate immune cell function. Mice lacking C9orf72 develop splenomegaly nad lymphadenopathy and accumulate swollen macrophage-like cells [175]. Loss of C9orf72 in mice also leads to macrophage and microglial dysfunction and age-related neuroinflammation similar to that described in C9orf72 fALS [175]. Again, these new findings raise the possibility of a dual pathogenic mechanism, in which the effects of microglial dysfunction from decreased C9orf72 expression combine with toxic by-products in neurons to promote neurodegeneration (Figure 2).

Immune actions may then precede ALS pathology and may be sufficient to cause it, suggesting that ALS is an autoimmune disease. A growing body of evidence supports this hypothesis. For example, circulating myeloid cells of ALS patients have a proinflammatory phenotype $[90,176]$, while regulatory $\mathrm{T}$ lymphocytes are decreased, enhancing neuroinflammation and disease progression [177]. Also, the up-regulation of inflammatory genes in arrays on samples from ALS patients suggests the involvement of immune actions in the ALS pathogenesis [178-180]. Some other studies have related motor neuron disease with autoimmune neuromuscular disorders. Around 30\% of ALS patients present decrement on repetitive nerve stimulation [181], and the risk of ALS is increased in people with concomitant myasthenia gravis [182]. This combination of ALS and myasthenia gravis has been reported to occur non-stochastically [183] and, although the reasons for the coincidence are unknown, it may involve a link between the immune system and ALS [156]. Taken together these results suggest that immune processes may drive ALS pathology independently of neural processes, exacerbating motor neuron injury and feeding a cyclic process that sustains neurodegeneration. 
As in other aspects of the disease, the nature of neuroinflammation in ALS is heterogeneous. In many cases adaptive immune cells may drive the pathological process, a feature that defines ALS as a neuroinflammatory disease rather than a neurodegenerative disorder [139]. However, this concept is far from being consolidated: it remains unclear how and when the immune system impacts the course of ALS, and it stills needs to be clarified whether an immune mechanism is involved in all patients.

\section{MICROGLIA MAY DRIVE ALS PATHOPHYSIOLOGY}

A key aspect of CNS function is the dynamic interaction between neurons and microglia. Therefore dysfunction of microglial non-inflammatory activity may contribute to pathological processes $[184,185]$. For exemple, excessive activation of microglial CD33 was found to upregulate synapse removal in Alzheimer's disease patiens and mouse models [186,187]. Also, altered microglial brain-derived neurotrophic factor signaling has been associated with neuropathic pain [123]. In this line, the axis fractalkine-CX3CR1 participates in the control of microglial dysfunction. Microglial CX3CR1, involved in neurotrophic fuctions, is upregulated in many pathological conditions [188]. The role of CX3CR1 in the control of neuroinflammation has been extensively studied in the CX3CR1-EGFP mouse line. Although the consequences of $\mathrm{CX} 3 \mathrm{CR} 1$ deletion in microglia largely depend on the mouse model used, the overall idea is that a lack of CX3CR1 leads to a hyperactivity of microglia in the diseased brain, thereby unleashing potential neurotoxic properties $[113,189,190]$. However, other evidence suggests that fractalkine sustains neuroinflammation and contributes to neurotoxicity (see [191] for a review). In any case, CX3CR1 signaling impairment has a direct influence on neurodegenerative diseases associated with neuroinflammation, microglia and/or T-cell recruitment [192,193]. 
In a cohort of Spanish sALS patients, a genetic association was described between the V249I and T280M variants in the human CX3CR1 gene and the progression rate and survival time [34]. This association has also been reported between these two CX3CR1 gene variants and some other inflammatory diseases, including multiple sclerosis, agerelated macular degeneration, AIDS, and coronary disease [194]. V249I and T280M genetic variants affect the activity of the CX3CR1 protein by reducing its affinity to fractalkine [195]. In animal models, CX3CR1-/- knockout mice inbred with the SOD1 ${ }^{\mathrm{G} 93 \mathrm{~A}}$ tg ALS model present a worsened disease outcome, more extensive neuronal loss and increased microglial activation [196]. As CX3CR1 is involved in microglial neurotrophic function (Figure 3), its reduced activity may exacerbate the proinflammatory activity of microglia.

What still remains to be established is whether the fractalkine-CX3CR 1 axis is affected in the diseased brain. There are few reports of fractalkine concentration in the brain and CX3CR1 expression in microglia during the course of disease. Cardona et al. [188] detected a rather high concentration of free fractalkine in the brain, which suggests a constitutive release under physiological conditions. In multiple sclerosis or epilepsy, the CNS levels of fractalkine and/or CX3CR1 were found either unchanged or increased $[197,198]$, indicating that the inhibitory function of the fractalkine-CX3CR1 axis is not generally weakened under diseased conditions.

Microvesicles (MVs) and exosomes are considered important players in the dynamic interactions between neurons and glia. In the CNS, neurons, microglia, astrocytes and oligodendrocytes release MVs and exosomes with different sizes and contents into the extracellular space. These particles can move freely through the extracellular medium and interact with different cell types by as yet undetermined mechanisms [199]. MVs carry and may shuttle specific proteins and noncoding nucleic acids such as microRNAs 
(miRNAs) [200]. In fact, some miRNA may be found in MVs at higher concentrations than in cells [201]. For these reasons, besides their potential as disease biomarkers [202], MVs and exosomes are considered to have a role in the pathogenesis and dissemination of inflammatory diseases.

The cell-to-cell transmission of TDP-43 and SOD1 misfolding, which is propagated by prionic mechanisms (see [52] for a review), now appears to be mediated by MVs trafficking. A recent study provides evidence for a primarily microvesicular intercellular spread of TDP-43 aggregates [203], and both neuronal and astroglial MVs have been implicated in the propagation of pathogenic misfolded SOD1. In vitro, motor neuron NSC-34 cells overexpressing wild type and mutant SOD1 secreted this protein via exosomes [204]. Astrocytes expressing mutant SOD1 release a high amount of exosomes carrying the protein and promote motor neuron death [205]. Interestingly, MVs from activated astroglia also transfer amino-acid transporter-1 [206], suggesting a possible role for them in the extracellular mechanism that curtails excitotoxicity.

There is growing evidence of the involvement of miRNA deregulation in ALS pathogenesis [207-211]. Changes in miRNA expression have been found in patients and the SOD $1^{\mathrm{G} 93 \mathrm{~A}}$ mouse $[176,212,213]$ reflecting a dysfunction of the expressed RNA binding proteins involved in ALS. miRNAs are stable in cerebrospinal fluid, serum and other body fluids as exosomal cargos [214] and their concentrations are also modified in ALS [215] suggesting that the dysfunction of RNA binding proteins in ALS is systemic. In serum of fALS patients, specific miRNAs non-related with the mutated gene are downregulated already in presymptomatic disease [216,217], whereas serum miRNA profiles are far more heterogeneous in sALS patients [218]. Other exosomal miRNAs are upregulated in ALS [219]. Some are components of the innate immune system and 
modify the pro-inflammatory NF- $\mathrm{BB}$ signaling pathway [220], indicating, again, a role for the immune system in ALS pathogenesis.

Finally, reactive microglia release MVs and exosomes, which may have a dual role in motor neuron degeneration (Figure 3). On the one hand, MVs released by reactive microglia carry pro-inflammatory cytokines [221] and induce an inflammatory reaction in target cells [222]. Microglia-derived MVs also promote precipitation of misfolded proteins in Parkinson's and Alzheimer's disease models [223,224]. On the other hand, microglia stimulated with interferon- $\gamma$ release exosomes that confer protection on surrounding cells [225]. Thus, different stimuli may trigger the microglial release of MVs with different composition and properties, as already described for macrophages and monocytes [226,227]. If true, microglial activation will lead to increased secretion of MVs, which differ in composition and are associated with ALS pathological processes with distinct roles. This possibility may open up new avenues in the development of treatments for ALS. Currently it is considered that, by engineering MVs, it will be possible to enhance the protective microglial phenotype in order to curtail neuroinflammation and promote tissue repair.

\section{NEUROINFLAMMATION AND ALS TREATMENTS}

The difficulty of developing effective treatments for ALS is explained, at least in part, by its heterogeneity and the presence of both functional and structural on-going cell damage. For years, the multiple ALS phenotypes and the identification of many mutations in the SOD1 gene that could not explain the disease were not little help in guiding pharmacological research; riluzole, introduced in 1995, is presently the sole authorized treatment, with limited efficacy and a high financial cost [228]. Since the 1990s, clinical trials with many other drugs have mostly yielded negative results, and 
there is an urgent need to define new and effective therapeutic strategies and improve clinical trials [229-231].

Protein aggregation and neuroinflammation are common features of the chronic course of ALS. Therefore the molecular mechanisms underlying these factors are potentially amenable to therapy. In this line, the compound BIIB067, a drug designed to reduce the production of SOD1, is currently in a phase I clinical trial (ClinicalTrials.gov ID: NCT02623699) [231]. With respect to neuroinflammation some patents protecting the development of anti-inflammatory compounds have been registered for use in ALS [232], but to our knowledge, none are being developed as part of current ALS therapeutic strategies [231]. In this context, in the search for valid ALS therapies, the standard view of neuroinflammation, which has focused mainly on the cytotoxic activity of microglia, is not longer valid. Instead this view should be replaced by an integrative approach that involves a wide spectrum of microglial phenotypes and recognizes the dynamic interactions between microglia, neurons, immune cells, and astrocytes.

\section{CONCLUDING REMARKS}

The causes and pathophysiology of ALS are far from being clarified. Recent years have seen notable gene discoveries in ALS, but only very modest progress in treatment. In spite of the large body of evidence provided, many questions remain unanswered. For example: Why do some individuals carrying a pathogenic SOD1 or C9orf72 mutation never develop ALS or FTD? Are they resistant to the disease? What is the real role of the immune system in the pathogenesis of the disease? Answers to these questions should help us to understand ALS and to find therapeutic solutions for this devastating disease. 
The involvement of microglia in non-inflammatory functions challenges our concept of neuroinflammation and opens up new research posibilities in the neuron-microglia crosstalk. In this new scenario, mechanisms such as the fractalkine-CX3CR1 axis or MVs and exosome trafficking appear as central players in this relationship. As these new functions are progressively characterized, the pathophysiological mechanisms of ALS will hopefully be revelated. In this pursuit, molecular characterization of the different ALS clinical presentations must allow an integrated view of the disease and enable new effective strategies for diagnosing and treating the condition. In the meantime, we can only continue to work hard and hope that we will see soon a giant step forward for humankind in the treatment of this pernicious killer disease.

\section{REVIEW CRITERIA}

Articles were identified from publications listed in English on PubMed to October 2016. Combinations of the following key words were used: "amyotrophic lateral sclerosis", "ALS", "motor neuron disease", "neuroinflammation", "microglia", “astroglia", “immune system", “excitotoxicity”, “environment”, “energy metabolism”, "nutrition", "risk factor", "phenotype", "neuron-glia interaction"," microvesicle", “exosome", "microRNA".

We also identified articles from the reference lists of the articles found with the abovecited search terms. Other publications were identified through the author's collections of scientific literature. Clinical trials were selected at the ClinicalTrials.gov database. The final reference list was generated on the basis of originality and relevance to the scope of this Review. 


\section{COMPETING INTERESTS}

The authors have no conflicts of interest to declare.

\section{REFERENCES}

[1] Cleveland, D. W.; Rothstein, J. D. From Charcot to Lou Gehrig: Deciphering Selective Motor Neuron Death in ALS. Nat. Rev. Neurosci. 2001, 2 (11), 806819.

[2] Turner, M.; Scaber, J.; Goodfellow, J.; Lord, M.; Marsden, R.; Talbot K. The Diagnostic Pathway and Prognosis in Bulbar-Onset Amyotrophic Lateral Sclerosis. J Neurol Sci. 2010, 294 (1-2), 81-85.

[3] Yoshida, S.; Mulder, D. W.; Kurland, L. T.; Chu, C. P.; Okazaki, H. Follow-up Study on Amyotrophic Lateral Sclerosis in Rochester, Minn., 1925 through 1984. Neuroepidemiology 1986, 5 (2), 61-70.

[4] Lu, Y.-P.; Lou, Y.-R.; Liao, J.; Xie, J.-G.; Peng, Q.-Y.; Yang, C. S.; Conney, A. H. Administration of Green Tea or Caffeine Enhances the Disappearance of UVB-Induced Patches of Mutant p53 Positive Epidermal Cells in SKH-1 Mice. Carcinogenesis 2005, 26 (8), 1465-1472.

[5] Charcot, J.; Joffroy, A. Deux Cas D'atrophie Musculaire Progressive Avec Lesions de La Substance Grise et Des Faisceaux Antero-Lateraux de La Moelle Epiniere. Arch Physiol Neurol Pathol 1869, 2, 744-754.

[6] Conte, A.; Lattante, S.; Luigetti, M.; Del Grande, A.; Romano, A.; Marcaccio, A.; Marangi, G.; Rossini, P. M.; Neri, G.; Zollino, M.; Sabatelli, M. Classification of Familial Amyotrophic Lateral Sclerosis by Family History: Effects on Frequency of Genes Mutation. J. Neurol. Neurosurg. Psychiatry 2012, 83 (12), 1201-1203.

[7] Cady, J.; Allred, P.; Bali, T.; Pestronk, A.; Goate, A.; Miller, T. M.; Mitra, R. D.; Ravits, J.; Harms, M. B.; Baloh, R. H. Amyotrophic Lateral Sclerosis Onset Is Influenced by the Burden of Rare Variants in Known Amyotrophic Lateral Sclerosis Genes. Ann. Neurol. 2015, 77 (1), 100-113.

[8] Sabatelli, M.; Zollino, M.; Luigetti, M.; Grande, A. Del; Lattante, S.; Marangi, G.; Monaco, M. Lo; Madia, F.; Meleo, E.; Bisogni, G.; Conte, A. Uncovering Amyotrophic Lateral Sclerosis Phenotypes: Clinical Features and Long-Term Follow-up of Upper Motor Neuron-Dominant ALS. Amyotroph. Lateral Scler. 2011, 12 (4), 278-282.

[9] Zou, Z.-Y.; Liu, M.-S.; Li, X.-G.; Cui, L.-Y. Mutations in FUS Are the Most Frequent Genetic Cause in Juvenile Sporadic ALS Patients of Chinese Origin. Amyotroph. Lateral Scler. Frontotemporal Degener. 17 (3-4), 249-252.

[10] Sabatelli, M.; Madia, F.; Conte, A.; Luigetti, M.; Zollino, M.; Mancuso, I.; Lo Monaco, M.; Lippi, G.; Tonali, P. Natural History of Young-Adult Amyotrophic Lateral Sclerosis. Neurology 2008, 71 (12), 876-881.

[11] Kiernan MC1, Vucic S, Cheah BC, Turner, M.; Eisen, A.; Hardiman, O.; Burrell, 
J.; Zoing MC. Amyotrophic Lateral Sclerosis. Lancet 2011, 377 (9769), 942955.

[12] Swinnen, B.; Robberecht, W. The Phenotypic Variability of Amyotrophic Lateral Sclerosis. Nat. Rev. Neurol. 2014, 10 (11), 661-670.

[13] The ALS research forum http://www.alsresearchforum.org/ (accessed Jun 20, 2006).

[14] Lomen-Hoerth, C.; Anderson, T.; Miller, B. The Overlap of Amyotrophic Lateral Sclerosis and Frontotemporal Dementia. Neurology 2002, 59 (7), 1077-1079.

[15] Mackenzie, I.; Baborie, A.; Pickering-Brown, S.; Du Plessis, D.; Jaros, E.; Perry, R. H.; Neary, D.; Snowden, J. S.; Mann, D. M. A. Heterogeneity of Ubiquitin Pathology in Frontotemporal Lobar Degeneration: Classification and Relation to Clinical Phenotype. Acta Neuropathol. 2006, 112 (5), 539-549.

[16] Mackenzie, I.; Rademakers, R.; Neumann M. TDP-43 and FUS in Amyotrophic Lateral Sclerosis and Frontotemporal Dementia. Lancet Neurol. 2010, 9 (10), 995-1007.

[17] Hsiung, G.-Y. R.; DeJesus-Hernandez, M.; Feldman, H. H.; Sengdy, P.; Bouchard-Kerr, P.; Dwosh, E.; Butler, R.; Leung, B.; Fok, A.; Rutherford, N. J.; Baker, M.; Rademakers, R.; Mackenzie, I. R. A. Clinical and Pathological Features of Familial Frontotemporal Dementia Caused by C9ORF72 Mutation on Chromosome 9p. Brain 2012, 135 (Pt 3), 709-722.

[18] Gordon, P. H.; Cheng, B.; Katz, I. B.; Mitsumoto, H.; Rowland, L. P. Clinical Features That Distinguish PLS, Upper Motor Neuron-Dominant ALS, and Typical ALS. Neurology 2009, 72 (22), 1948-1952.

[19] Sabatelli, M.; Conte, A.; Zollino, M. Clinical and Genetic Heterogeneity of Amyotrophic Lateral Sclerosis. Clin. Genet. 2013, 83 (5), 408-416.

[20] Stewart, H.; Rutherford, N. J.; Briemberg, H.; Krieger, C.; Cashman, N.; Fabros, M.; Baker, M.; Fok, A.; DeJesus-Hernandez, M.; Eisen, A.; Rademakers, R.; Mackenzie, I. R. A. Clinical and Pathological Features of Amyotrophic Lateral Sclerosis Caused by Mutation in the C9ORF72 Gene on Chromosome 9p. Acta Neuropathol. 2012, 123 (3), 409-417.

[21] Beghi, E. Are Professional Soccer Players at Higher Risk for ALS? Amyotroph. Lateral Scler. Frontotemporal Degener. 2013, 14 (7-8), 501-506.

[22] Belli, S.; Vanacore, N. Proportionate Mortality of Italian Soccer Players: Is Amyotrophic Lateral Sclerosis an Occupational Disease? Eur. J. Epidemiol. 2005, 20 (3), 237-242.

[23] Veldink, J. H.; Kalmijn, S.; Groeneveld, G. J.; Titulaer, M. J.; Wokke, J. H. J.; van den Berg, L. H. Physical Activity and the Association with Sporadic ALS. Neurology 2005, 64 (2), 241-245.

[24] Horner, R. D.; Kamins, K. G.; Feussner, J. R.; Grambow, S. C.; Hoff-Lindquist, J.; Harati, Y.; Mitsumoto, H.; Pascuzzi, R.; Spencer, P. S.; Tim, R.; Howard, D.; Smith, T. C.; Ryan, M. A. K.; Coffman, C. J.; Kasarskis, E. J. Occurrence of Amyotrophic Lateral Sclerosis among Gulf War Veterans. Neurology 2003, 61 (6), 742-749.

[25] Weisskopf, M. G.; Cudkowicz, M. E.; Johnson, N. Military Service and 
Amyotrophic Lateral Sclerosis in a Population-Based Cohort. Epidemiology 2015, 26 (6), 831-838.

[26] Bozzoni, V.; Pansarasa, O.; Diamanti, L.; Nosari, G.; Cereda, C.; Ceroni, M. Amyotrophic Lateral Sclerosis and Environmental Factors. Funct. Neurol. 31 (1), 7-19.

[27] Capozzella, A.; Sacco, C.; Chighine, A.; Loreti, B.; Scala, B.; Casale, T.; Sinibaldi, F.; Tomei, G.; Giubilati, R.; Tomei, F.; Rosati, M. V. Work Related Etiology of Amyotrophic Lateral Sclerosis (ALS): A Meta-Analysis. Ann. di Ig. Med. Prev. e di comunità 26 (5), 456-472.

[28] Malek, A.; Barchowsky, A.; Bowser, R.; Youk, A.; Talbott, E. Pesticide Exposure as a Risk Factor for Amyotrophic Lateral Sclerosis: A Meta-Analysis of Epidemiological Studies: Pesticide Exposure as a Risk Factor for ALS. Environ. Res. 2012, 117, 112-119.

[29] Su, F.-C.; Goutman, S. A.; Chernyak, S.; Mukherjee, B.; Callaghan, B. C.; Batterman, S.; Feldman, E. L. Association of Environmental Toxins With Amyotrophic Lateral Sclerosis. JAMA Neurol. 2016.

[30] Pasinelli, P.; Brown, R. H. Molecular Biology of Amyotrophic Lateral Sclerosis: Insights from Genetics. Nat. Rev. Neurosci. 2006, 7 (9), 710-723.

[31] Shaw, P. J. Molecular and Cellular Pathways of Neurodegeneration in Motor Neurone Disease. J. Neurol. Neurosurg. Psychiatry 2005, 76 (8), 1046-1057.

[32] ALSoD database http://alsod.iop.kcl.ac.uk/ (accessed Jun 1, 2016).

[33] Millecamps, S.; Salachas, F.; Cazeneuve, C.; Gordon, P.; Bricka, B.; Camuzat, A.; Guillot-Noël, L.; Russaouen, O.; Bruneteau, G.; Pradat, P.-F.; Le Forestier, N.; Vandenberghe, N.; Danel-Brunaud, V.; Guy, N.; Thauvin-Robinet, C.; Lacomblez, L.; Couratier, P.; Hannequin, D.; Seilhean, D.; Le Ber, I.; Corcia, P.; Camu, W.; Brice, A.; Rouleau, G.; LeGuern, E.; Meininger, V. SOD1, ANG, VAPB, TARDBP, and FUS Mutations in Familial Amyotrophic Lateral Sclerosis: Genotype-Phenotype Correlations. J. Med. Genet. 2010, 47 (8), 554560 .

[34] Lopez-Lopez, A.; Gamez, J.; Syriani, E.; Morales, M.; Salvado, M.; Rodríguez, M. J.; Mahy, N.; Vidal-Taboada, J. M. CX3CR1 Is a Modifying Gene of Survival and Progression in Amyotrophic Lateral Sclerosis. PLoS One 2014, 9 (5), e96528.

[35] Landers, J. E.; Melki, J.; Meininger, V.; Glass, J. D.; van den Berg, L. H.; van Es, M. A.; Sapp, P. C.; van Vught, P. W. J.; McKenna-Yasek, D. M.; Blauw, H. M.; Cho, T.-J.; Polak, M.; Shi, L.; Wills, A.-M.; Broom, W. J.; Ticozzi, N.; Silani, V.; Ozoguz, A.; Rodriguez-Leyva, I.; Veldink, J. H.; Ivinson, A. J.; Saris, C. G. J.; Hosler, B. A.; Barnes-Nessa, A.; Couture, N.; Wokke, J. H. J.; Kwiatkowski, T. J.; Ophoff, R. A.; Cronin, S.; Hardiman, O.; Diekstra, F. P.; Leigh, P. N.; Shaw, C. E.; Simpson, C. L.; Hansen, V. K.; Powell, J. F.; Corcia, P.; Salachas, F.; Heath, S.; Galan, P.; Georges, F.; Horvitz, H. R.; Lathrop, M.; Purcell, S.; AlChalabi, A.; Brown, R. H. Reduced Expression of the Kinesin-Associated Protein 3 (KIFAP3) Gene Increases Survival in Sporadic Amyotrophic Lateral Sclerosis. Proc. Natl. Acad. Sci. U. S. A. 2009, 106 (22), 9004-9009.

[36] van Es, M. A.; Veldink, J. H.; Saris, C. G. J.; Blauw, H. M.; van Vught, P. W. J.; 
Birve, A.; Lemmens, R.; Schelhaas, H. J.; Groen, E. J. N.; Huisman, M. H. B.; van der Kooi, A. J.; de Visser, M.; Dahlberg, C.; Estrada, K.; Rivadeneira, F.; Hofman, A.; Zwarts, M. J.; van Doormaal, P. T. C.; Rujescu, D.; Strengman, E.; Giegling, I.; Muglia, P.; Tomik, B.; Slowik, A.; Uitterlinden, A. G.; Hendrich, C.; Waibel, S.; Meyer, T.; Ludolph, A. C.; Glass, J. D.; Purcell, S.; Cichon, S.; Nöthen, M. M.; Wichmann, H.-E.; Schreiber, S.; Vermeulen, S. H. H. M.; Kiemeney, L. A.; Wokke, J. H. J.; Cronin, S.; McLaughlin, R. L.; Hardiman, O.; Fumoto, K.; Pasterkamp, R. J.; Meininger, V.; Melki, J.; Leigh, P. N.; Shaw, C. E.; Landers, J. E.; Al-Chalabi, A.; Brown, R. H.; Robberecht, W.; Andersen, P. M.; Ophoff, R. A.; van den Berg, L. H. Genome-Wide Association Study Identifies 19p13.3 (UNC13A) and 9p21.2 as Susceptibility Loci for Sporadic Amyotrophic Lateral Sclerosis. Nat. Genet. 2009, 41 (10), 1083-1087.

[37] Van Hoecke, A.; Schoonaert, L.; Lemmens, R.; Timmers, M.; Staats, K. A.; Laird, A. S.; Peeters, E.; Philips, T.; Goris, A.; Dubois, B.; Andersen, P. M.; AlChalabi, A.; Thijs, V.; Turnley, A. M.; van Vught, P. W.; Veldink, J. H.; Hardiman, O.; Van Den Bosch, L.; Gonzalez-Perez, P.; Van Damme, P.; Brown, R. H.; van den Berg, L. H.; Robberecht, W. EPHA4 Is a Disease Modifier of Amyotrophic Lateral Sclerosis in Animal Models and in Humans. Nat. Med. 2012, 18 (9), 1418-1422.

[38] Vidal-Taboada, J. M.; Lopez-Lopez, A.; Salvado, M.; Lorenzo, L.; Garcia, C.; Mahy, N.; Rodríguez, M. J.; Gamez, J. UNC13A Confers Risk for Sporadic ALS and Influences Survival in a Spanish Cohort. J. Neurol. 2015, 262 (10), 22852292.

[39] Rosen, D. R.; Siddique, T.; Patterson, D.; Figlewicz, D. A.; Sapp, P.; Hentati, A.; Donaldson, D.; Goto, J.; O’Regan, J. P.; Deng, H. X. Mutations in $\mathrm{Cu} / \mathrm{Zn}$ Superoxide Dismutase Gene Are Associated with Familial Amyotrophic Lateral Sclerosis. Nature 1993, 362 (6415), 59-62.

[40] Al-Chalabi, A.; Jones, A.; Troakes, C.; King, A.; Al-Sarraj, S.; van den Berg, L. H. The Genetics and Neuropathology of Amyotrophic Lateral Sclerosis. Acta Neuropathol. 2012, 124 (3), 339-352.

[41] Chiò, A.; Traynor, B. J.; Lombardo, F.; Fimognari, M.; Calvo, A.; Ghiglione, P.; Mutani, R.; Restagno, G. Prevalence of SOD1 Mutations in the Italian ALS Population. Neurology 2008, 70 (7), 533-537.

[42] Renton, A. E.; Chiò, A.; Traynor, B. J. State of Play in Amyotrophic Lateral Sclerosis Genetics. Nat. Neurosci. 2014, 17 (1), 17-23.

[43] Restagno, G.; Gomez, A.; Lombardo, F.; Cocco, E.; Calvo, A.; Ghiglione, P.; Mutani, R.; Chiò, A. The IVS1 +319 T\&gt;a of SOD1 Gene Is Not an ALS Causing Mutation. Amyotroph. Lateral Scler. Other Motor Neuron Disord. 2005, $6(1), 45-49$.

[44] Ingre, C.; Wuolikainen, A.; Marklund, S. L.; Birve, A.; Press, R.; Andersen, P. M. A 50 Bp Deletion in the SOD1 Promoter Lowers Enzyme Expression but Is Not Associated with ALS in Sweden. Amyotroph. Lateral Scler. Frontotemporal Degener. 2016, 1-6.

[45] Bruijn, L.; Becher, M.; Lee, M.; Anderson, K.; Jenkins, N.; Copeland, N.; Sisodia, S.; Rothstein, J.; Borchelt, D.; Price, D.; Cleveland, D. ALS-Linked SOD1 Mutant G85R Mediates Damage to Astrocytes and Promotes Rapidly 
Progressive Disease with SOD1-Containing Inclusions. Neuron 1997, 18 (2), $327-338$.

[46] Gurney, M. E.; Pu, H.; Chiu, A. Y.; Dal Canto, M. C.; Polchow, C. Y.; Alexander, D. D.; Caliendo, J.; Hentati, A.; Kwon, Y. W.; Deng, H. X. Motor Neuron Degeneration in Mice That Express a Human $\mathrm{Cu}, \mathrm{Zn}$ Superoxide Dismutase Mutation. Science 1994, 264 (5166), 1772-1775.

[47] Wong, P.; Pardo, C.; Borchelt, D.; Lee, M.; Copeland, N.; Jenkins, N.; Sisodia, S.; Cleveland, D.; Price, D. An Adverse Property of a Familial ALS-Linked SOD1 Mutation Causes Motor Neuron Disease Characterized by Vacuolar Degeneration of Mitochondria. Neuron 1995, 14 (6), 1105-1116.

[48] Forsberg, K.; Jonsson, P. A.; Andersen, P. M.; Bergemalm, D.; Graffmo, K. S.; Hultdin, M.; Jacobsson, J.; Rosquist, R.; Marklund, S. L.; Brännström, T. Novel Antibodies Reveal Inclusions Containing Non-Native SOD1 in Sporadic ALS Patients. PLoS One 2010, 5 (7), e11552.

[49] Bosco, D. A.; Morfini, G.; Karabacak, N. M.; Song, Y.; Gros-Louis, F.; Pasinelli, P.; Goolsby, H.; Fontaine, B. A.; Lemay, N.; McKenna-Yasek, D.; Frosch, M. P.; Agar, J. N.; Julien, J.-P.; Brady, S. T.; Brown, R. H. Wild-Type and Mutant SOD1 Share an Aberrant Conformation and a Common Pathogenic Pathway in ALS. Nat. Neurosci. 2010, 13 (11), 1396-1403.

[50] Synofzik, M.; Ronchi, D.; Keskin, I.; Basak, A. N.; Wilhelm, C.; Gobbi, C.; Birve, A.; Biskup, S.; Zecca, C.; Fernández-Santiago, R.; Kaugesaar, T.; Schöls, L.; Marklund, S. L.; Andersen, P. M. Mutant Superoxide Dismutase-1 Indistinguishable from Wild-Type Causes ALS. Hum. Mol. Genet. 2012, 21 (16), 3568-3574.

[51] Graffmo, K. S.; Forsberg, K.; Bergh, J.; Birve, A.; Zetterström, P.; Andersen, P. M.; Marklund, S. L.; Brännström, T. Expression of Wild-Type Human Superoxide Dismutase-1 in Mice Causes Amyotrophic Lateral Sclerosis. Hum. Mol. Genet. 2013, 22 (1), 51-60.

[52] Grad, L.; Fernando, S.; Cashman, N. From Molecule to Molecule and Cell to Cell: Prion-like Mechanisms in Amyotrophic Lateral Sclerosis. Neurobiol Dis 2015, 77, 257-265.

[53] Parakh, S.; Atkin, J. D. Protein Folding Alterations in Amyotrophic Lateral Sclerosis. Brain Res. 2016, 1648 (Pt B), 633-649.

[54] Corrado, L.; Battistini, S.; Penco, S.; Bergamaschi, L.; Testa, L.; Ricci, C.; Giannini, F.; Greco, G.; Patrosso, M.; Pileggi, S.; Causarano R; Mazzini L; Momigliano-Richiardi, P.; D'Alfonso S. Variations in the Coding and Regulatory Sequences of the Angiogenin (ANG) Gene Are Not Associated to ALS (Amyotrophic Lateral Sclerosis) in the Italian Population. J. Neurol. Sci. 2007, $258(1-2), 123-127$.

[55] Cirulli, E. T.; Lasseigne, B. N.; Petrovski, S.; Sapp, P. C.; Dion, P. A.; Leblond, C. S.; Couthouis, J.; Lu, Y.-F.; Wang, Q.; Krueger, B. J.; Ren, Z.; Keebler, J.; Han, Y.; Levy, S. E.; Boone, B. E.; Wimbish, J. R.; Waite, L. L.; Jones, A. L.; Carulli, J. P.; Day-Williams, A. G.; Staropoli, J. F.; Xin, W. W.; Chesi, A.; Raphael, A. R.; McKenna-Yasek, D.; Cady, J.; Vianney de Jong, J. M. B.; Kenna, K. P.; Smith, B. N.; Topp, S.; Miller, J.; Gkazi, A.; FALS Sequencing Consortium; Al-Chalabi, A.; van den Berg, L. H.; Veldink, J.; Silani, V.; Ticozzi, 
N.; Shaw, C. E.; Baloh, R. H.; Appel, S.; Simpson, E.; Lagier-Tourenne, C.; Pulst, S. M.; Gibson, S.; Trojanowski, J. Q.; Elman, L.; McCluskey, L.; Grossman, M.; Shneider, N. A.; Chung, W. K.; Ravits, J. M.; Glass, J. D.; Sims, K. B.; Van Deerlin, V. M.; Maniatis, T.; Hayes, S. D.; Ordureau, A.; Swarup, S.; Landers, J.; Baas, F.; Allen, A. S.; Bedlack, R. S.; Harper, J. W.; Gitler, A. D.; Rouleau, G. A.; Brown, R.; Harms, M. B.; Cooper, G. M.; Harris, T.; Myers, R. M.; Goldstein, D. B. Exome Sequencing in Amyotrophic Lateral Sclerosis Identifies Risk Genes and Pathways. Science 2015, 347 (6229), 1436-1441.

[56] Morsch, M.; Radford, R.; Lee, A.; Don, E. K.; Badrock, A. P.; Hall, T. E.; Cole, N. J.; Chung, R. In Vivo Characterization of Microglial Engulfment of Dying Neurons in the Zebrafish Spinal Cord. Front. Cell. Neurosci. 2015, 9, 321.

[57] van Blitterswijk, M.; van Es, M.; Koppers, M.; van Rheenen, W.; Medic, J.; Schelhaas, H.; van der Kooi, A.; de Visser, M.; Veldink, J.; van den Berg, L. VAPB and C9orf72 Mutations in 1 Familial Amyotrophic Lateral Sclerosis Patient. Neurobiol. Aging 2012, 33 (12), 2950.e1-4.

[58] Nishimura, A. L.; Al-Chalabi, A.; Zatz, M. A Common Founder for Amyotrophic Lateral Sclerosis Type 8 (ALS8) in the Brazilian Population. Hum. Genet. 2005, $118(3-4), 499-500$.

[59] Langou, K.; Moumen, A.; Pellegrino, C.; Aebischer, J.; Medina, I.; Aebischer, P.; Raoul, C. AAV-Mediated Expression of Wild-Type and ALS-Linked Mutant VAPB Selectively Triggers Death of Motoneurons through a Ca2+-Dependent ER-Associated Pathway. J. Neurochem. 2010, 114 (3), 795-809.

[60] Suzuki, H.; Kanekura, K.; Levine, T. P.; Kohno, K.; Olkkonen, V. M.; Aiso, S.; Matsuoka, M. ALS-Linked P56S-VAPB, an Aggregated Loss-of-Function Mutant of VAPB, Predisposes Motor Neurons to ER Stress-Related Death by Inducing Aggregation of Co-Expressed Wild-Type VAPB. J. Neurochem. 2009, 108 (4), 973-985.

[61] DeJesus-Hernandez, M.; Mackenzie, I.; Boeve, B.; Boxer, A.; Baker, M.; Rutherford, N.; Nicholson, A.; Finch, N.; Flynn, H.; Adamson, J.; Kouri, N.; Wojtas, A.; Sengdy, P.; Hsiung, G.; Karydas, A.; Seeley, W.; Josephs, K.; Coppola, G.; Geschwind, D.; Wszolek, Z.; Feldman, H.; Knopman, D.; Petersen, R.; Miller, B.; Dickson, D.; Boylan, K.; Graff-Radford, N.; Rademakers, R. Expanded GGGGCC Hexanucleotide Repeat in Noncoding Region of C9ORF72 Causes Chromosome 9p-Linked FTD and ALS. Neuron 2011, 72 (2), 245-265.

[62] Kwon, I.; Xiang, S.; Kato, M.; Wu, L.; Theodoropoulos, P.; Wang, T.; Kim, J.; Yun, J.; Xie, Y.; McKnight, S. L. Poly-Dipeptides Encoded by the C9orf72 Repeats Bind Nucleoli, Impede RNA Biogenesis, and Kill Cells. Science 2014, 345 (6201), 1139-1145.

[63] Renton, A.; Majounie, E.; Waite, A.; Simón-Sánchez, J.; Rollinson, S.; Gibbs, J.; Schymick, J.; Laaksovirta, H.; van Swieten, J.; Myllykangas, L.; Kalimo, H.; Paetau, A.; Abramzon, Y.; Remes, A.; Kaganovich, A.; Scholz, S.; Duckworth, J.; Ding, J.; Harmer, D.; Hernandez, D.; Johnson, J.; Mok, K.; Ryten, M.; Trabzuni, D.; Guerreiro, R.; Orrell, R.; Neal, J.; Murray, A.; Pearson, J.; Jansen, I.; Sondervan, D.; Seelaar, H.; Blake, D.; Young, K.; Halliwell, N.; Callister, J.; Toulson, G.; Richardson, A.; Gerhard, A.; Snowden, J.; Mann, D.; Neary, D.; Nalls, M.; Peuralinna, T.; Jansson, L.; Isoviita, V.; Kaivorinne, A.; Hölttä-Vuori, M.; Ikonen, E.; Sulkava, R.; Benatar, M.; Wuu, J.; Chiò, A.; Restagno, G.; 
Borghero, G.; Sabatelli, M.; ITALSGEN Consortium; Heckerman, D.; Rogaeva, E.; Zinman, L.; Rothstein, J.; Sendtner, M.; Drepper, C.; Eichler, E.; Alkan, C.; Abdullaev, Z.; Pack, S.; Dutra, A.; Pak, E.; Hardy, J.; Singleton, A.; Williams, N.; Heutink, P.; Pickering-Brown, S.; Morris, H.; Tienari, P.; Traynor, B. A Hexanucleotide Repeat Expansion in C9ORF72 Is the Cause of Chromosome 9p21-Linked ALS-FTD. Neuron 2011, 72 (2), 257-268.

[64] van Rheenen, W.; Shatunov, A.; Dekker, A. M.; McLaughlin, R. L.; Diekstra, F. P.; Pulit, S. L.; van der Spek, R. A. A.; Võsa, U.; de Jong, S.; Robinson, M. R.; Yang, J.; Fogh, I.; van Doormaal, P. T.; Tazelaar, G. H. P.; Koppers, M.; Blokhuis, A. M.; Sproviero, W.; Jones, A. R.; Kenna, K. P.; van Eijk, K. R.; Harschnitz, O.; Schellevis, R. D.; Brands, W. J.; Medic, J.; Menelaou, A.; Vajda, A.; Ticozzi, N.; Lin, K.; Rogelj, B.; Vrabec, K.; Ravnik-Glavač, M.; Koritnik, B.; Zidar, J.; Leonardis, L.; Grošelj, L. D.; Millecamps, S.; Salachas, F.; Meininger, V.; de Carvalho, M.; Pinto, S.; Mora, J. S.; Rojas-García, R.; Polak, M.; Chandran, S.; Colville, S.; Swingler, R.; Morrison, K. E.; Shaw, P. J.; Hardy, J.; Orrell, R. W.; Pittman, A.; Sidle, K.; Fratta, P.; Malaspina, A.; Topp, S.; Petri, S.; Abdulla, S.; Drepper, C.; Sendtner, M.; Meyer, T.; Ophoff, R. A.; Staats, K. A.; Wiedau-Pazos, M.; Lomen-Hoerth, C.; Van Deerlin, V. M.; Trojanowski, J. Q.; Elman, L.; McCluskey, L.; Basak, A. N.; Tunca, C.; Hamzeiy, H.; Parman, Y.; Meitinger, T.; Lichtner, P.; Radivojkov-Blagojevic, M.; Andres, C. R.; Maurel, C.; Bensimon, G.; Landwehrmeyer, B.; Brice, A.; Payan, C. A. M.; Saker-Delye, S.; Dürr, A.; Wood, N. W.; Tittmann, L.; Lieb, W.; Franke, A.; Rietschel, M.; Cichon, S.; Nöthen, M. M.; Amouyel, P.; Tzourio, C.; Dartigues, J.-F.; Uitterlinden, A. G.; Rivadeneira, F.; Estrada, K.; Hofman, A.; Curtis, C.; Blauw, H. M.; van der Kooi, A. J.; de Visser, M.; Goris, A.; Weber, M.; Shaw, C. E.; Smith, B. N.; Pansarasa, O.; Cereda, C.; Del Bo, R.; Comi, G. P.; D’Alfonso, S.; Bertolin, C.; Sorarù, G.; Mazzini, L.; Pensato, V.; Gellera, C.; Tiloca, C.; Ratti, A.; Calvo, A.; Moglia, C.; Brunetti, M.; Arcuti, S.; Capozzo, R.; Zecca, C.; Lunetta, C.; Penco, S.; Riva, N.; Padovani, A.; Filosto, M.; Muller, B.; Stuit, R. J.; PARALS Registry; SLALOM Group; SLAP Registry; FALS Sequencing Consortium; SLAGEN Consortium; NNIPPS Study Group; Blair, I.; Zhang, K.; McCann, E. P.; Fifita, J. A.; Nicholson, G. A.; Rowe, D. B.; Pamphlett, R.; Kiernan, M. C.; Grosskreutz, J.; Witte, O. W.; Ringer, T.; Prell, T.; Stubendorff, B.; Kurth, I.; Hübner, C. A.; Leigh, P. N.; Casale, F.; Chio, A.; Beghi, E.; Pupillo, E.; Tortelli, R.; Logroscino, G.; Powell, J.; Ludolph, A. C.; Weishaupt, J. H.; Robberecht, W.; Van Damme, P.; Franke, L.; Pers, T. H.; Brown, R. H.; Glass, J. D.; Landers, J. E.; Hardiman, O.; Andersen, P. M.; Corcia, P.; Vourc'h, P.; Silani, V.; Wray, N. R.; Visscher, P. M.; de Bakker, P. I. W.; van Es, M. A.; Pasterkamp, R. J.; Lewis, C. M.; Breen, G.; Al-Chalabi, A.; van den Berg, L. H.; Veldink, J. H. Genome-Wide Association Analyses Identify New Risk Variants and the Genetic Architecture of Amyotrophic Lateral Sclerosis. Nat. Genet. 2016, 48 (9), 1043-1048.

[65] Guerreiro, R.; Brás, J.; Hardy, J. SnapShot: Genetics of ALS and FTD. Cell 2015, 160 (4), 798.e1.

[66] Tan, R. H.; Kril, J. J.; Fatima, M.; McGeachie, A.; McCann, H.; Shepherd, C.; Forrest, S. L.; Affleck, A.; Kwok, J. B. J.; Hodges, J. R.; Kiernan, M. C.; Halliday, G. M. TDP-43 Proteinopathies: Pathological Identification of Brain Regions Differentiating Clinical Phenotypes. Brain 2015, 138 (Pt 10), 31103122 . 
[67] Scotter, E. L.; Chen, H.-J.; Shaw, C. E. TDP-43 Proteinopathy and ALS: Insights into Disease Mechanisms and Therapeutic Targets. Neurotherapeutics 2015, 12 (2), 352-363.

[68] Morales, R.; Moreno-Gonzalez, I.; Soto, C. Cross-Seeding of Misfolded Proteins: Implications for Etiology and Pathogenesis of Protein Misfolding Diseases. PLoS Pathog. 2013, 9 (9), e1003537.

[69] Rodríguez, M. J.; Bernal, F.; Andrés, N.; Malpesa, Y.; Mahy, N. Excitatory Amino Acids and Neurodegeneration: A Hypothetical Role of Calcium Precipitation. Int. J. Dev. Neurosci. 2000, 18 (2-3), 299-307.

[70] Zou, Y.; Sun, Y.; Zhu, Y.; Ma, B.; Nussinov, R.; Zhang, Q. Critical Nucleus Structure and Aggregation Mechanism of the C-Terminal Fragment of CopperZinc Superoxide Dismutase Protein. ACS Chem. Neurosci. 2016, 7 (3), 286-296.

[71] Hwang, Y.-M.; Stathopulos, P. B.; Dimmick, K.; Yang, H.; Badiei, H. R.; Tong, M. S.; Rumfeldt, J. A. O.; Chen, P.; Karanassios, V.; Meiering, E. M. Nonamyloid Aggregates Arising from Mature Copper/zinc Superoxide Dismutases Resemble Those Observed in Amyotrophic Lateral Sclerosis. J. Biol. Chem. 2010, 285 (53), 41701-41711.

[72] Gitler, A. D.; Shorter, J. RNA-Binding Proteins with Prion-like Domains in ALS and FTLD-U. Prion 2011, 5 (3), 179-187.

[73] Moumen, A.; Virard, I.; Raoul, C. Accumulation of Wildtype and ALS-Linked Mutated VAPB Impairs Activity of the Proteasome. PLoS One 2011, 6 (10), e26066.

[74] Lee, J.-Y.; Kawaguchi, Y.; Li, M.; Kapur, M.; Choi, S. J.; Kim, H.-J.; Park, S.Y.; Zhu, H.; Yao, T.-P. Uncoupling of Protein Aggregation and Neurodegeneration in a Mouse Amyotrophic Lateral Sclerosis Model. Neurodegener. Dis. 2015, 15 (6), 339-349.

[75] Tudor, E.; Galtrey, C.; Perkinton, M.; Lau, K.; De Vos, K.; Mitchell, J.; Ackerley, S.; Hortobágyi, T.; Vámos, E.; Leigh, P.; Klasen, C.; McLoughlin, D.; Shaw, C.; Miller, C. Amyotrophic Lateral Sclerosis Mutant Vesicle-Associated Membrane Protein-Associated Protein-B Transgenic Mice Develop TAR-DNABinding Protein-43 Pathology. Neuroscience 2010, 167 (3), 774-785.

[76] Vijayalakshmi, K.; Alladi, P.; Ghosh, S.; Prasanna, V.; Sagar, B.; Nalini, A.; Sathyaprabha, T.; Raju, T. Evidence of Endoplasmic Reticular Stress in the Spinal Motor Neurons Exposed to CSF from Sporadic Amyotrophic Lateral Sclerosis Patients. Neurobiol. Dis. 2011, 41 (3), 695-705.

[77] Zhao, W.; Beers, D. R.; Henkel, J. S.; Zhang, W.; Urushitani, M.; Julien, J.-P.; Appel, S. H. Extracellular Mutant SOD1 Induces Microglial-Mediated Motoneuron Injury. Glia 2010, 58 (2), 231-243.

[78] Radford, R. A.; Morsch, M.; Rayner, S. L.; Cole, N. J.; Pountney, D. L.; Chung, R. S. The Established and Emerging Roles of Astrocytes and Microglia in Amyotrophic Lateral Sclerosis and Frontotemporal Dementia. Front. Cell. Neurosci. 2015, 9, 414.

[79] King, A. E.; Dickson, T. C.; Blizzard, C. A.; Foster, S. S.; Chung, R. S.; West, A. K.; Chuah, M. I.; Vickers, J. C. Excitotoxicity Mediated by Non-NMDA Receptors Causes Distal Axonopathy in Long-Term Cultured Spinal Motor 
Neurons. Eur. J. Neurosci. 2007, 26 (8), 2151-2159.

[80] Jonasson, S.; Eriksson, J.; Berntzon, L.; Spácil, Z.; Ilag, L. L.; Ronnevi, L.-O.; Rasmussen, U.; Bergman, B. Transfer of a Cyanobacterial Neurotoxin within a Temperate Aquatic Ecosystem Suggests Pathways for Human Exposure. Proc. Natl. Acad. Sci. U. S. A. 2010, 107 (20), 9252-9257.

[81] Yin, H.; Yu, S.; Hsu, C.; Liu, J.; Acab, A.; Wu, R.; Tao, A.; Chiang, B.; Weiss, J. Intrathecal Infusion of BMAA Induces Selective Motor Neuron Damage and Astrogliosis in the Ventral Horn of the Spinal Cord. Exp. Neurol. 2014, 261, 1-9.

[82] Hertz, L.; Peng, L.; Dienel, G. A. Energy Metabolism in Astrocytes: High Rate of Oxidative Metabolism and Spatiotemporal Dependence on Glycolysis/glycogenolysis. J. Cereb. Blood Flow Metab. 2007, 27 (2), 219-249.

[83] Gimeno-Bayón, J.; López-López, A.; Rodríguez, M. J.; Mahy, N. Glucose Pathways Adaptation Supports Acquisition of Activated Microglia Phenotype. $J$. Neurosci. Res. 2014, 92 (6), 723-731.

[84] Ramonet, D.; Rodríguez, M. J.; Fredriksson, K.; Bernal, F.; Mahy, N. In Vivo Neuroprotective Adaptation of the Glutamate/glutamine Cycle to Neuronal Death. Hippocampus 2004, 14 (5), 586-594.

[85] Falkowska, A.; Gutowska, I.; Goschorska, M.; Nowacki, P.; Chlubek, D.; Baranowska-Bosiacka, I. Energy Metabolism of the Brain, Including the Cooperation between Astrocytes and Neurons, Especially in the Context of Glycogen Metabolism. Int. J. Mol. Sci. 2015, 16 (11), 25959-25981.

[86] Feuerstein, D.; Backes, H.; Gramer, M.; Takagaki, M.; Gabel, P.; Kumagai, T.; Graf, R. Regulation of Cerebral Metabolism during Cortical Spreading Depression. J. Cereb. Blood Flow Metab. 2015.

[87] Pellerin, L. Lactate as a Pivotal Element in Neuron-Glia Metabolic Cooperation. Neurochem. Int. 43 (4-5), 331-338.

[88] Proia, P.; Di Liegro, C. M.; Schiera, G.; Fricano, A.; Di Liegro, I. Lactate as a Metabolite and a Regulator in the Central Nervous System. Int. J. Mol. Sci. 2016, 17 (9).

[89] Tipping, K. W.; Karamanos, T. K.; Jakhria, T.; Iadanza, M. G.; Goodchild, S. C.; Tuma, R.; Ranson, N. A.; Hewitt, E. W.; Radford, S. E. pH-Induced Molecular Shedding Drives the Formation of Amyloid Fibril-Derived Oligomers. Proc. Natl. Acad. Sci. U. S. A. 2015, 112 (18), 5691-5696.

[90] Puentes, F.; Malaspina, A.; van Noort, J. M.; Amor, S. Non-Neuronal Cells in ALS: Role of Glial, Immune Cells and Blood-CNS Barriers. Brain Pathol. 2016, 26 (2), 248-257.

[91] Ilieva, H.; Polymenidou, M.; Cleveland, D. W. Non-Cell Autonomous Toxicity in Neurodegenerative Disorders: ALS and Beyond. J. Cell Biol. 2009, 187 (6), 761-772.

[92] Komine, O.; Yamanaka, K. Neuroinflammation in Motor Neuron Disease. Nagoya J. Med. Sci. 2015, 77 (4), 537-549.

[93] Valdmanis, P. N.; Rouleau, G. A. Genetics of Familial Amyotrophic Lateral Sclerosis. Neurology 2008, 70 (2), 144-152.

[94] Dupuis, L.; Pradat, P.; Ludolph, A.; Loeffler, J. Energy Metabolism in 
Amyotrophic Lateral Sclerosis. Lancet Neurol. 2011, 10 (1), 75-82.

[95] Su, F.-C.; Goutman, S. A.; Chernyak, S.; Mukherjee, B.; Callaghan, B. C.; Batterman, S.; Feldman, E. L. Association of Environmental Toxins With Amyotrophic Lateral Sclerosis. JAMA Neurol. 2016.

[96] Yu, Y.; Su, F.-C.; Callaghan, B. C.; Goutman, S. A.; Batterman, S. A.; Feldman, E. L. Environmental Risk Factors and Amyotrophic Lateral Sclerosis (ALS): A Case-Control Study of ALS in Michigan. PLoS One 2014, 9 (6), e101186.

[97] Valbuena, G. N.; Rizzardini, M.; Cimini, S.; Siskos, A. P.; Bendotti, C.; Cantoni, L.; Keun, H. C. Metabolomic Analysis Reveals Increased Aerobic Glycolysis and Amino Acid Deficit in a Cellular Model of Amyotrophic Lateral Sclerosis. Mol. Neurobiol. 2016, 53 (4), 2222-2240.

[98] Liesa, M.; Shirihai, O. Mitochondrial Dynamics in the Regulation of Nutrient Utilization and Energy Expenditure. Cell Metab. 2013, 17 (4), 491-506.

[99] Wright, R. H. G.; Lioutas, A.; Le Dily, F.; Soronellas, D.; Pohl, A.; Bonet, J.; Nacht, A. S.; Samino, S.; Font-Mateu, J.; Vicent, G. P.; Wierer, M.; Trabado, M. A.; Schelhorn, C.; Carolis, C.; Macias, M. J.; Yanes, O.; Oliva, B.; Beato, M. ADP-Ribose-Derived Nuclear ATP Synthesis by NUDIX5 Is Required for Chromatin Remodeling. Science 2016, 352 (6290), 1221-1225.

[100] Liu, W.; Yamashita, T.; Tian, F.; Morimoto, N.; Ikeda, Y.; Deguchi, K.; Abe, K. Mitochondrial Fusion and Fission Proteins Expression Dynamically Change in a Murine Model of Amyotrophic Lateral Sclerosis. Curr. Neurovasc. Res. 2013, 10 (3), 222-230.

[101] Fidler, J. A.; Treleaven, C. M.; Frakes, A.; Tamsett, T. J.; McCrate, M.; Cheng, S. H.; Shihabuddin, L. S.; Kaspar, B. K.; Dodge, J. C. Disease Progression in a Mouse Model of Amyotrophic Lateral Sclerosis: The Influence of Chronic Stress and Corticosterone. FASEB J. 2011, 25 (12), 4369-4377.

[102] Rodríguez, M. J.; Prats, A.; Malpesa, Y.; Andrés, N.; Pugliese, M.; Batlle, M.; Mahy, N. Pattern of Injury with a Graded Excitotoxic Insult and Ensuing Chronic Medial Septal Damage in the Rat Brain. J. Neurotrauma 2009, 26 (10), 18231834.

[103] Steiner, J. L.; Bardgett, M. E.; Wolfgang, L.; Lang, C. H.; Stocker, S. D. Glucocorticoids Attenuate the Central Sympathoexcitatory Actions of Insulin. $J$. Neurophysiol. 2014, 112 (10), 2597-2604.

[104] Duncan, M. W.; Steele, J. C.; Kopin, I. J.; Markey, S. P. 2-Amino-3(Methylamino)-Propanoic Acid (BMAA) in Cycad Flour: An Unlikely Cause of Amyotrophic Lateral Sclerosis and Parkinsonism-Dementia of Guam. Neurology 1990, 40 (5), 767-772.

[105] Genton, L.; Viatte, V.; Janssens, J.; Héritier, A.; Pichard, C. Nutritional State, Energy Intakes and Energy Expenditure of Amyotrophic Lateral Sclerosis (ALS) Patients. Clin. Nutr. 2011, 30 (5), 553-559.

[106] Spencer, P. S. Guam ALS/parkinsonism-Dementia: A Long-Latency Neurotoxic Disorder Caused by \&quot;slow Toxin(s)\&quot; in Food? Can. J. Neurol. Sci. 1987, 14 (3 Suppl), 347-357.

[107] Henkel, J. S.; Beers, D. R.; Zhao, W.; Appel, S. H. Microglia in ALS: The Good, the Bad, and the Resting. J. Neuroimmune Pharmacol. 2009, 4 (4), 389-398. 
[108] Philips, T.; Robberecht, W. Neuroinflammation in Amyotrophic Lateral Sclerosis: Role of Glial Activation in Motor Neuron Disease. Lancet Neurol 2011, 10 (3), 253-263.

[109] Engelhardt, J. I.; Tajti, J.; Appel, S. H. Lymphocytic Infiltrates in the Spinal Cord in Amyotrophic Lateral Sclerosis. Arch. Neurol. 1993, 50 (1), 30-36.

[110] Turner, M.; Cagnin, A.; Turkheimer, F.; Miller, C.; Shaw, C.; Brooks, D.; Leigh, P.; Banati, R. Evidence of Widespread Cerebral Microglial Activation in Amyotrophic Lateral Sclerosis: An [11C](R)-PK11195 Positron Emission Tomography Study. Neurobiol Dis 2004, 15 (3), 601-609.

[111] Wormser, U.; Mandrioli, J.; Vinceti, M.; Fini, N.; Sintov, A.; Brodsky, B.; Proskura, E.; Finkelstein, Y. Reduced Levels of Alpha-1-Antitrypsin in Cerebrospinal Fluid of Amyotrophic Lateral Sclerosis Patients: A Novel Approach for a Potential Treatment. J. Neuroinflammation 2016, 13 (1), 131.

[112] Chiu, I.; Morimoto, E.; Goodarzi, H.; Liao, J.; O’Keeffe, S.; Phatnani, H.; Muratet, M.; Carroll, M.; Levy, S.; Tavazoie, S.; Myers, R.; Maniatis, T. A Neurodegeneration-Specific Gene-Expression Signature of Acutely Isolated Microglia from an Amyotrophic Lateral Sclerosis Mouse Model. Cell Rep 2013, $4(2), 385-401$.

[113] Hellwig, S.; Heinrich, A.; Biber, K. The Brain's Best Friend: Microglial Neurotoxicity Revisited. Front. Cell. Neurosci. 2013, 7, 71.

[114] Rentzos, M.; Rombos, A.; Nikolaou, C.; Zoga, M.; Zouvelou, V.; Dimitrakopoulos, A.; Alexakis, T.; Tsoutsou, A.; Samakovli, A.; Michalopoulou, M.; Evdokimidis, J. Interleukin-17 and Interleukin-23 Are Elevated in Serum and Cerebrospinal Fluid of Patients with ALS: A Reflection of Th17 Cells Activation? Acta Neurol. Scand. 2010, 122 (6), 425-429.

[115] Mitchell, R. M.; Freeman, W. M.; Randazzo, W. T.; Stephens, H. E.; Beard, J. L.; Simmons, Z.; Connor, J. R. A CSF Biomarker Panel for Identification of Patients with Amyotrophic Lateral Sclerosis. Neurology 2009, 72 (1), 14-19.

[116] Kettenmann, H.; Hanisch, U.-K.; Noda, M.; Verkhratsky, A. Physiology of Microglia. Physiol. Rev. 2011, 91 (2), 461-553.

[117] Koizumi, S.; Ohsawa, K.; Inoue, K.; Kohsaka, S. Purinergic Receptors in Microglia: Functional Modal Shifts of Microglia Mediated by P2 and P1 Receptors. Glia 2013, 61 (1), 47-54.

[118] Domercq, M.; Vázquez-Villoldo, N.; Matute, C. Neurotransmitter Signaling in the Pathophysiology of Microglia. Front. Cell. Neurosci. 2013, 7, 49.

[119] Wake, H.; Moorhouse, A. J.; Jinno, S.; Kohsaka, S.; Nabekura, J. Resting Microglia Directly Monitor the Functional State of Synapses in Vivo and Determine the Fate of Ischemic Terminals. J. Neurosci. 2009, 29 (13), 39743980.

[120] Rodríguez, M. J.; Martínez-Moreno, M.; Ortega, F. J.; Mahy, N. Targeting Microglial K(ATP) Channels to Treat Neurodegenerative Diseases: A Mitochondrial Issue. Oxid. Med. Cell. Longev. 2013, 2013, 194546.

[121] Schafer, D. P.; Lehrman, E. K.; Stevens, B. The "quad-Partite" Synapse: Microglia-Synapse Interactions in the Developing and Mature CNS. Glia 2013, $61(1), 24-36$. 
[122] Salter, M.; Beggs, S. Sublime Microglia: Expanding Roles for the Guardians of the CNS. Cell 2014, 158 (1), 15-24.

[123] Parkhurst, C. N.; Yang, G.; Ninan, I.; Savas, J. N.; Yates, J. R.; Lafaille, J. J.; Hempstead, B. L.; Littman, D. R.; Gan, W.-B. Microglia Promote LearningDependent Synapse Formation through Brain-Derived Neurotrophic Factor. Cell 2013, 155 (7), 1596-1609.

[124] Frankland, P. W.; Köhler, S.; Josselyn, S. A. Hippocampal Neurogenesis and Forgetting. Trends Neurosci. 2013, 36 (9), 497-503.

[125] Sierra, A.; Encinas, J.; Deudero, J.; Chancey, J.; Enikolopov, G.; OverstreetWadiche, L.; Tsirka, S.; Maletic-Savatic, M. Microglia Shape Adult Hippocampal Neurogenesis through Apoptosis-Coupled Phagocytosis. Cell Stem Cell 2010, 7 (4), 483-495.

[126] Milior, G.; Lecours, C.; Samson, L.; Bisht, K.; Poggini, S.; Pagani, F.; Deflorio, C.; Lauro, C.; Alboni, S.; Limatola, C.; Branchi, I.; Tremblay, M.-E.; Maggi, L. Fractalkine Receptor Deficiency Impairs Microglial and Neuronal Responsiveness to Chronic Stress. Brain. Behav. Immun. 2016, 55, 114-125.

[127] Riazi, K.; Galic, M. A.; Kentner, A. C.; Reid, A. Y.; Sharkey, K. A.; Pittman, Q. J. Microglia-Dependent Alteration of Glutamatergic Synaptic Transmission and Plasticity in the Hippocampus during Peripheral Inflammation. J. Neurosci. 2015, 35 (12), 4942-4952.

[128] Bian, C.; Zhao, Z.-Q.; Zhang, Y.-Q.; Lü, N. Involvement of CX3CL1/CX3CR1 Signaling in Spinal Long Term Potentiation. PLoS One 2015, 10 (3), e0118842.

[129] Zhang, J.; Malik, A.; Choi, H. B.; Ko, R. W. Y.; Dissing-Olesen, L.; MacVicar, B. A. Microglial CR3 Activation Triggers Long-Term Synaptic Depression in the Hippocampus via NADPH Oxidase. Neuron 2014, 82 (1), 195-207.

[130] Bessis, A.; Béchade, C.; Bernard, D.; Roumier, A. Microglial Control of Neuronal Death and Synaptic Properties. Glia 2007, 55 (3), 233-238.

[131] Miyamoto, A.; Wake, H.; Ishikawa, A. W.; Eto, K.; Shibata, K.; Murakoshi, H.; Koizumi, S.; Moorhouse, A. J.; Yoshimura, Y.; Nabekura, J. Microglia Contact Induces Synapse Formation in Developing Somatosensory Cortex. Nat. Commun. 2016, 7, 12540.

[132] Harrison, J. K.; Jiang, Y.; Chen, S.; Xia, Y.; Maciejewski, D.; McNamara, R. K.; Streit, W. J.; Salafranca, M. N.; Adhikari, S.; Thompson, D. A.; Botti, P.; Bacon, K. B.; Feng, L. Role for Neuronally Derived Fractalkine in Mediating Interactions between Neurons and CX3CR1-Expressing Microglia. Proc. Natl. Acad. Sci. U. S. A. 1998, 95 (18), 10896-10901.

[133] Kim, K.-W.; Vallon-Eberhard, A.; Zigmond, E.; Farache, J.; Shezen, E.; Shakhar, G.; Ludwig, A.; Lira, S. A.; Jung, S. In Vivo Structure/function and Expression Analysis of the CX3C Chemokine Fractalkine. Blood 2011, 118 (22), e156-67.

[134] Paolicelli, R. C.; Bolasco, G.; Pagani, F.; Maggi, L.; Scianni, M.; Panzanelli, P.; Giustetto, M.; Ferreira, T. A.; Guiducci, E.; Dumas, L.; Ragozzino, D.; Gross, C. T. Synaptic Pruning by Microglia Is Necessary for Normal Brain Development. Science 2011, 333 (6048), 1456-1458.

[135] Zhan, Y.; Paolicelli, R. C.; Sforazzini, F.; Weinhard, L.; Bolasco, G.; Pagani, F.; Vyssotski, A. L.; Bifone, A.; Gozzi, A.; Ragozzino, D.; Gross, C. T. Deficient 
Neuron-Microglia Signaling Results in Impaired Functional Brain Connectivity and Social Behavior. Nat. Neurosci. 2014, 17 (3), 400-406.

[136] Ortega, F. J.; Vukovic, J.; Rodríguez, M. J.; Bartlett, P. F. Blockade of Microglial KATP -Channel Abrogates Suppression of Inflammatory-Mediated Inhibition of Neural Precursor Cells. Glia 2014, 62 (2), 247-258.

[137] Virgili, N.; Espinosa-Parrilla, J. F.; Mancera, P.; Pastén-Zamorano, A.; GimenoBayon, J.; Rodríguez, M. J.; Mahy, N.; Pugliese, M. Oral Administration of the KATP Channel Opener Diazoxide Ameliorates Disease Progression in a Murine Model of Multiple Sclerosis. J. Neuroinflammation 2011, 8 (1), 149.

[138] Espinosa-Parrilla, J. F.; Martínez-Moreno, M.; Gasull, X.; Mahy, N.; Rodríguez, M. J. The L-Type Voltage-Gated Calcium Channel Modulates Microglial proInflammatory Activity. Mol. Cell. Neurosci. 2015, 64, 104-115.

[139] Heppner, F. L.; Ransohoff, R. M.; Becher, B. Immune Attack: The Role of Inflammation in Alzheimer Disease. Nat. Rev. Neurosci. 2015, 16 (6), 358-372.

[140] Ortega, F. J.; Gimeno-Bayon, J.; Espinosa-Parrilla, J. F.; Carrasco, J. L.; Batlle, M.; Pugliese, M.; Mahy, N.; Rodríguez, M. J. ATP-Dependent Potassium Channel Blockade Strengthens Microglial Neuroprotection after HypoxiaIschemia in Rats. Exp. Neurol. 2012, 235 (1), 282-296.

[141] Czeh, M.; Gressens, P.; Kaindl, A. M. The Yin and Yang of Microglia. Dev. Neurosci. 2011, 33 (3-4), 199-209.

[142] DiSabato, D.; Quan, N.; Godbout, J. P. Neuroinflammation: The Devil Is in the Details. J. Neurochem. 2016.

[143] Block, M. L.; Zecca, L.; Hong, J.-S. Microglia-Mediated Neurotoxicity: Uncovering the Molecular Mechanisms. Nat. Rev. Neurosci. 2007, 8 (1), 57-69.

[144] Beers, D. R.; Henkel, J. S.; Zhao, W.; Wang, J.; Appel, S. H. CD4+ T Cells Support Glial Neuroprotection, Slow Disease Progression, and Modify Glial Morphology in an Animal Model of Inherited ALS. Proc. Natl. Acad. Sci. U. S. A. 2008, 105 (40), 15558-15563.

[145] Batlle, M.; Ferri, L.; Andrade, C.; Ortega, F.-J.; Vidal-Taboada, J. M.; Pugliese, M.; Mahy, N.; Rodríguez, M. J. Astroglia-Microglia Cross Talk during Neurodegeneration in the Rat Hippocampus. Biomed Res. Int. 2015, 2015, 102419.

[146] Lewis, K. E.; Rasmussen, A. L.; Bennett, W.; King, A.; West, A. K.; Chung, R. S.; Chuah, M. I. Microglia and Motor Neurons during Disease Progression in the SOD1G93A Mouse Model of Amyotrophic Lateral Sclerosis: Changes in arginase1 and Inducible Nitric Oxide Synthase. J. Neuroinflammation 2014, 11, 55 .

[147] Murray, P.; Allen, J.; Biswas, S.; Fisher, E.; Gilroy, D.; Goerdt, S.; Gordon, S.; Hamilton, J.; Ivashkiv, L.; Lawrence, T.; Locati, M.; Mantovani, A.; Martinez, F.; Mege, J.; Mosser, D.; Natoli, G.; Saeij, J.; Schultze, J.; Shirey, K.; Sica, A.; Suttles, J.; Udalova, I.; van Ginderachter, J.; Vogel, S.; Wynn, T. Macrophage Activation and Polarization: Nomenclature and Experimental Guidelines. Immunity 2014, 41 (1), 14-20.

[148] Salter, M. W.; Beggs, S. Sublime Microglia: Expanding Roles for the Guardians of the CNS. Cell 2014, 158 (1), 15-24. 
[149] Narai, H.; Nagano, I.; Ilieva, H.; Shiote, M.; Nagata, T.; Hayashi, T.; Shoji, M.; Abe, K. Prevention of Spinal Motor Neuron Death by Insulin-like Growth Factor-1 Associating with the Signal Transduction Systems in SODG93A Transgenic Mice. J. Neurosci. Res. 2005, 82 (4), 452-457.

[150] Laird, A. S.; Van Hoecke, A.; De Muynck, L.; Timmers, M.; Van den Bosch, L.; Van Damme, P.; Robberecht, W. Progranulin Is Neurotrophic in Vivo and Protects against a Mutant TDP-43 Induced Axonopathy. PLoS One 2010, 5 (10), e13368.

[151] Rosen, E. Y.; Wexler, E. M.; Versano, R.; Coppola, G.; Gao, F.; Winden, K. D.; Oldham, M. C.; Martens, L. H.; Zhou, P.; Farese, R. V; Geschwind, D. H. Functional Genomic Analyses Identify Pathways Dysregulated by Progranulin Deficiency, Implicating Wnt Signaling. Neuron 2011, 71 (6), 1030-1042.

[152] Maruyama, H.; Morino, H.; Ito, H.; Izumi, Y.; Kato, H.; Watanabe, Y.; Kinoshita, Y.; Kamada, M.; Nodera, H.; Suzuki, H.; Komure, O.; Matsuura, S.; Kobatake, K.; Morimoto, N.; Abe, K.; Suzuki, N.; Aoki, M.; Kawata, A.; Hirai, T.; Kato, T.; Ogasawara, K.; Hirano, A.; Takumi, T.; Kusaka, H.; Hagiwara, K.; Kaji, R.; Kawakami, H. Mutations of Optineurin in Amyotrophic Lateral Sclerosis. Nature 2010, 465 (7295), 223-226.

[153] Pottier, C.; Bieniek, K. F.; Finch, N.; van de Vorst, M.; Baker, M.; Perkersen, R.; Brown, P.; Ravenscroft, T.; van Blitterswijk, M.; Nicholson, A. M.; DeTure, M.; Knopman, D. S.; Josephs, K. A.; Parisi, J. E.; Petersen, R. C.; Boylan, K. B.; Boeve, B. F.; Graff-Radford, N. R.; Veltman, J. A.; Gilissen, C.; Murray, M. E.; Dickson, D. W.; Rademakers, R. Whole-Genome Sequencing Reveals Important Role for TBK1 and OPTN Mutations in Frontotemporal Lobar Degeneration without Motor Neuron Disease. Acta Neuropathol. 2015, 130 (1), 77-92.

[154] Sakaguchi, T.; Irie, T.; Kawabata, R.; Yoshida, A.; Maruyama, H.; Kawakami, H. Optineurin with Amyotrophic Lateral Sclerosis-Related Mutations Abrogates Inhibition of Interferon Regulatory Factor-3 Activation. Neurosci. Lett. 2011, 505 (3), 279-281.

[155] Lorenzl, S.; Narr, S.; Angele, B.; Krell, H. W.; Gregorio, J.; Kiaei, M.; Pfister, H.-W.; Beal, M. F. The Matrix Metalloproteinases Inhibitor Ro 28-2653 [Correction of Ro 26-2853] Extends Survival in Transgenic ALS Mice. Exp. Neurol. 2006, 200 (1), 166-171.

[156] Hooten, K. G.; Beers, D. R.; Zhao, W.; Appel, S. H. Protective and Toxic Neuroinflammation in Amyotrophic Lateral Sclerosis. Neurotherapeutics 2015, 12 (2), 364-375.

[157] Yamanaka, K.; Chun, S. J.; Boillee, S.; Fujimori-Tonou, N.; Yamashita, H.; Gutmann, D. H.; Takahashi, R.; Misawa, H.; Cleveland, D. W. Astrocytes as Determinants of Disease Progression in Inherited Amyotrophic Lateral Sclerosis. Nat. Neurosci. 2008, 11 (3), 251-253.

[158] Haidet-Phillips, A. M.; Hester, M. E.; Miranda, C. J.; Meyer, K.; Braun, L.; Frakes, A.; Song, S.; Likhite, S.; Murtha, M. J.; Foust, K. D.; Rao, M.; Eagle, A.; Kammesheidt, A.; Christensen, A.; Mendell, J. R.; Burghes, A. H. M.; Kaspar, B. K. Astrocytes from Familial and Sporadic ALS Patients Are Toxic to Motor Neurons. Nat. Biotechnol. 2011, 29 (9), 824-828.

[159] Khakh, B. S.; Sofroniew, M. V. Diversity of Astrocyte Functions and Phenotypes 
in Neural Circuits. Nat. Neurosci. 2015, 18 (7), 942-952.

[160] Nagy, D.; Kato, T.; Kushner, P. D. Reactive Astrocytes Are Widespread in the Cortical Gray Matter of Amyotrophic Lateral Sclerosis. J. Neurosci. Res. 1994, 38 (3), 336-347.

[161] Schiffer, D.; Cordera, S.; Cavalla, P.; Migheli, A. Reactive Astrogliosis of the Spinal Cord in Amyotrophic Lateral Sclerosis. J. Neurol. Sci. 1996, 139 Suppl, 27-33.

[162] Levine, J. B.; Kong, J.; Nadler, M.; Xu, Z. Astrocytes Interact Intimately with Degenerating Motor Neurons in Mouse Amyotrophic Lateral Sclerosis (ALS). Glia 1999, 28 (3), 215-224.

[163] Neumann, H.; Boucraut, J.; Hahnel, C.; Misgeld, T.; Wekerle, H. Neuronal Control of MHC Class II Inducibility in Rat Astrocytes and Microglia. Eur. J. Neurosci. 1996, 8 (12), 2582-2590.

[164] Nagai, M.; Re, D. B.; Nagata, T.; Chalazonitis, A.; Jessell, T. M.; Wichterle, H.; Przedborski, S. Astrocytes Expressing ALS-Linked Mutated SOD1 Release Factors Selectively Toxic to Motor Neurons. Nat. Neurosci. 2007, 10 (5), 615622.

[165] Farina, C.; Aloisi, F.; Meinl, E. Astrocytes Are Active Players in Cerebral Innate Immunity. TRends Immunol 2007, 28 (3), 138-145.

[166] Navarrete, M.; Perea, G.; Maglio, L.; Pastor, J.; García de Sola, R.; Araque, A. Astrocyte Calcium Signal and Gliotransmission in Human Brain Tissue. Cereb. Cortex 2013, 23 (5), 1240-1246.

[167] Rothstein, J. D.; Martin, L. J.; Kuncl, R. W. Decreased Glutamate Transport by the Brain and Spinal Cord in Amyotrophic Lateral Sclerosis. N. Engl. J. Med. 1992, 326 (22), 1464-1468.

[168] Medina, L.; Figueredo-Cardenas, G.; Rothstein, J.; Reiner, A. Differential Abundance of Glutamate Transporter Subtypes in Amyotrophic Lateral Sclerosis (ALS)-Vulnerable versus ALS-Resistant Brain Stem Motor Cell Groups. Exp Neurol 1996, 142 (2), 287-295.

[169] Almad, A. A.; Doreswamy, A.; Gross, S. K.; Richard, J.-P.; Huo, Y.; Haughey, N.; Maragakis, N. J. Connexin 43 in Astrocytes Contributes to Motor Neuron Toxicity in Amyotrophic Lateral Sclerosis. Glia 2016, 64 (7), 1154-1169.

[170] Hall, E. D.; Oostveen, J. A.; Gurney, M. E. Relationship of Microglial and Astrocytic Activation to Disease Onset and Progression in a Transgenic Model of Familial ALS. Glia 1998, 23 (3), 249-256.

[171] Henkel, J. S.; Engelhardt, J. I.; Siklós, L.; Simpson, E. P.; Kim, S. H.; Pan, T.; Goodman, J. C.; Siddique, T.; Beers, D. R.; Appel, S. H. Presence of Dendritic Cells, MCP-1, and Activated Microglia/macrophages in Amyotrophic Lateral Sclerosis Spinal Cord Tissue. Ann. Neurol. 2004, 55 (2), 221-235.

[172] Zhao, W.; Beers, D.; Bell, S.; Wang, J.; Wen, S.; Baloh, R.; Appel, S. TDP-43 Activates Microglia through NF- $\kappa \mathrm{B}$ and NLRP3 Inflammasome. Exp Neurol 2015, 273, 24-35.

[173] Swarup, V.; Phaneuf, D.; Bareil, C.; Robertson, J.; Rouleau, G. A.; Kriz, J.; Julien, J.-P. Pathological Hallmarks of Amyotrophic Lateral 
Sclerosis/frontotemporal Lobar Degeneration in Transgenic Mice Produced with TDP-43 Genomic Fragments. Brain 2011, 134 (Pt 9), 2610-2626.

[174] Swarup, V.; Phaneuf, D.; Dupré, N.; Petri, S.; Strong, M.; Kriz, J.; Julien, J.-P. Deregulation of TDP-43 in Amyotrophic Lateral Sclerosis Triggers Nuclear Factor кB-Mediated Pathogenic Pathways. J. Exp. Med. 2011, 208 (12), 24292447.

[175] O’Rourke, J. G.; Bogdanik, L.; Yáñez, A.; Lall, D.; Wolf, A. J.; Muhammad, A. K. M. G.; Ho, R.; Carmona, S.; Vit, J. P.; Zarrow, J.; Kim, K. J.; Bell, S.; Harms, M. B.; Miller, T. M.; Dangler, C. A.; Underhill, D. M.; Goodridge, H. S.; Lutz, C. M.; Baloh, R. H. C9orf72 Is Required for Proper Macrophage and Microglial Function in Mice. Science 2016, 351 (6279), 1324-1329.

[176] Butovsky, O.; Siddiqui, S.; Gabriely, G.; Lanser, A. J.; Dake, B.; Murugaiyan, G.; Doykan, C. E.; Wu, P. M.; Gali, R. R.; Iyer, L. K.; Lawson, R.; Berry, J.; Krichevsky, A. M.; Cudkowicz, M. E.; Weiner, H. L. Modulating Inflammatory Monocytes with a Unique microRNA Gene Signature Ameliorates Murine ALS. J. Clin. Invest. 2012, 122 (9), 3063-3087.

[177] Henkel, J. S.; Beers, D. R.; Wen, S.; Rivera, A. L.; Toennis, K. M.; Appel, J. E.; Zhao, W.; Moore, D. H.; Powell, S. Z.; Appel, S. H. Regulatory T-Lymphocytes Mediate Amyotrophic Lateral Sclerosis Progression and Survival. EMBO Mol. Med. 2013, 5 (1), 64-79.

[178] Mougeot, J.-L. C.; Li, Z.; Price, A. E.; Wright, F. A.; Brooks, B. R. Microarray Analysis of Peripheral Blood Lymphocytes from ALS Patients and the SAFE Detection of the KEGG ALS Pathway. BMC Med. Genomics 2011, 4, 74.

[179] Zhang, R.; Hadlock, K.; Do, H.; Yu, S.; Honrada, R.; Champion, S.; Forshew, D.; Madison, C.; Katz, J.; Miller, R.; McGrath, M. Gene Expression Profiling in Peripheral Blood Mononuclear Cells from Patients with Sporadic Amyotrophic Lateral Sclerosis (sALS). J Neuroimmunol 2011, 230 (1-2), 114-123.

[180] Li, M. D.; Burns, T. C.; Morgan, A. A.; Khatri, P. Integrated Multi-Cohort Transcriptional Meta-Analysis of Neurodegenerative Diseases. Acta Neuropathol. Commun. 2014, 2, 93.

[181] Killian, J. M.; Wilfong, A. A.; Burnett, L.; Appel, S. H.; Boland, D. Decremental Motor Responses to Repetitive Nerve Stimulation in ALS. Muscle Nerve 1994, 17 (7), 747-754.

[182] Turner, M. R.; Goldacre, R.; Ramagopalan, S.; Talbot, K.; Goldacre, M. J. Autoimmune Disease Preceding Amyotrophic Lateral Sclerosis: An Epidemiologic Study. Neurology 2013, 81 (14), 1222-1225.

[183] Del Mar Amador, M.; Vandenberghe, N.; Berhoune, N.; Camdessanché, J.; Gronier, S.; Delmont, E.; Desnuelle, C.; Cintas, P.; Pittion, S.; Louis, S.; Demeret, S.; Lenglet, T.; Meininger, V.; Salachas, F.; Pradat, P.; Bruneteau, G. Unusual Association of Amyotrophic Lateral Sclerosis and Myasthenia Gravis: A Dysregulation of the Adaptive Immune System? Neuromuscul Disord 2016, 26 (6), 342-346.

[184] Edmonson, C. A.; Ziats, M. N.; Rennert, O. M. A Non-Inflammatory Role for Microglia in Autism Spectrum Disorders. Front. Neurol. 2016, 7, 9.

[185] Fourgeaud, L.; Través, P. G.; Tufail, Y.; Leal-Bailey, H.; Lew, E. D.; Burrola, P. 
G.; Callaway, P.; Zagórska, A.; Rothlin, C. V; Nimmerjahn, A.; Lemke, G. TAM Receptors Regulate Multiple Features of Microglial Physiology. Nature 2016, 532 (7598), 240-244.

[186] Griciuc, A.; Serrano-Pozo, A.; Parrado, A. R.; Lesinski, A. N.; Asselin, C. N.; Mullin, K.; Hooli, B.; Choi, S. H.; Hyman, B. T.; Tanzi, R. E. Alzheimer's Disease Risk Gene CD33 Inhibits Microglial Uptake of Amyloid Beta. Neuron 2013, 78 (4), 631-643.

[187] Zhang, B.; Gaiteri, C.; Bodea, L.-G.; Wang, Z.; McElwee, J.; Podtelezhnikov, A. A.; Zhang, C.; Xie, T.; Tran, L.; Dobrin, R.; Fluder, E.; Clurman, B.; Melquist, S.; Narayanan, M.; Suver, C.; Shah, H.; Mahajan, M.; Gillis, T.; Mysore, J.; MacDonald, M. E.; Lamb, J. R.; Bennett, D. A.; Molony, C.; Stone, D. J.; Gudnason, V.; Myers, A. J.; Schadt, E. E.; Neumann, H.; Zhu, J.; Emilsson, V. Integrated Systems Approach Identifies Genetic Nodes and Networks in LateOnset Alzheimer's Disease. Cell 2013, 153 (3), 707-720.

[188] Cardona, A. E.; Pioro, E. P.; Sasse, M. E.; Kostenko, V.; Cardona, S. M.; Dijkstra, I. M.; Huang, D.; Kidd, G.; Dombrowski, S.; Dutta, R.; Lee, J.-C.; Cook, D. N.; Jung, S.; Lira, S. A.; Littman, D. R.; Ransohoff, R. M. Control of Microglial Neurotoxicity by the Fractalkine Receptor. Nat. Neurosci. 2006, 9 (7), 917-924.

[189] Pabon, M. M.; Bachstetter, A. D.; Hudson, C. E.; Gemma, C.; Bickford, P. C. CX3CL1 Reduces Neurotoxicity and Microglial Activation in a Rat Model of Parkinson's Disease. J. Neuroinflammation 2011, 8, 9.

[190] Wolf, Y.; Yona, S.; Kim, K.-W.; Jung, S. Microglia, Seen from the CX3CR1 Angle. Front. Cell. Neurosci. 2013, 7, 26.

[191] Lauro, C.; Catalano, M.; Trettel, F.; Limatola, C. Fractalkine in the Nervous System: Neuroprotective or Neurotoxic Molecule? Ann. N. Y. Acad. Sci. 2015, $1351,141-148$.

[192] Ransohoff, R. M.; Cardona, A. E. The Myeloid Cells of the Central Nervous System Parenchyma. Nature 2010, 468 (7321), 253-262.

[193] Hertwig, L.; Hamann, I.; Romero-Suarez, S.; Millward, J. M.; Pietrek, R.; Chanvillard, C.; Stuis, H.; Pollok, K.; Ransohoff, R. M.; Cardona, A. E.; InfanteDuarte, C. CX3CR1-Dependent Recruitment of Mature NK Cells into the Central Nervous System Contributes to Control Autoimmune Neuroinflammation. Eur. J. Immunol. 2016, 46 (8), 1984-1996.

[194] Daoudi, M.; Lavergne, E.; Garin, A.; Tarantino, N.; Debré, P.; Pincet, F.; Combadière, C.; Deterre, P. Enhanced Adhesive Capacities of the Naturally Occurring Ile249-Met280 Variant of the Chemokine Receptor CX3CR1. J. Biol. Chem. 2004, 279 (19), 19649-19657.

[195] McDermott, D. H.; Fong, A. M.; Yang, Q.; Sechler, J. M.; Cupples, L. A.; Merrell, M. N.; Wilson, P. W. F.; D’Agostino, R. B.; O’Donnell, C. J.; Patel, D. D.; Murphy, P. M. Chemokine Receptor Mutant CX3CR1-M280 Has Impaired Adhesive Function and Correlates with Protection from Cardiovascular Disease in Humans. J. Clin. Invest. 2003, 111 (8), 1241-1250.

[196] Troost, D.; Van den Oord, J. J.; Vianney de Jong, J. M. Immunohistochemical Characterization of the Inflammatory Infiltrate in Amyotrophic Lateral Sclerosis. 
Neuropathol. Appl. Neurobiol. 1990, 16 (5), 401-410.

[197] Hulshof, S.; van Haastert, E. S.; Kuipers, H. F.; van den Elsen, P. J.; De Groot, C. J.; van der Valk, P.; Ravid, R.; Biber, K. CX3CL1 and CX3CR1 Expression in Human Brain Tissue: Noninflammatory Control versus Multiple Sclerosis. J. Neuropathol. Exp. Neurol. 2003, 62 (9), 899-907.

[198] Xu, Y.; Zeng, K.; Han, Y.; Wang, L.; Chen, D.; Xi, Z.; Wang, H.; Wang, X.; Chen, G. Altered Expression of CX3CL1 in Patients with Epilepsy and in a Rat Model. Am J Pathol 2012, 180 (5), 1950-1962.

[199] Lachenal, G.; Pernet-Gallay, K.; Chivet, M.; Hemming, F.; Belly, A.; Bodon, G.; Blot, B.; Haase, G.; Goldberg, Y.; Sadoul, R. Release of Exosomes from Differentiated Neurons and Its Regulation by Synaptic Glutamatergic Activity. Mol Cell Neurosci 2011, 46 (2), 409-418.

[200] Bronisz, A.; Wang, Y.; Nowicki, M. O.; Peruzzi, P.; Ansari, K. I.; Ogawa, D.; Balaj, L.; De Rienzo, G.; Mineo, M.; Nakano, I.; Ostrowski, M. C.; Hochberg, F.; Weissleder, R.; Lawler, S. E.; Chiocca, E. A.; Godlewski, J. Extracellular Vesicles Modulate the Glioblastoma Microenvironment via a Tumor Suppression Signaling Network Directed by miR-1. Cancer Res. 2014, 74 (3), 738-750.

[201] Paschon, V.; Takada, S. H.; Ikebara, J. M.; Sousa, E.; Raeisossadati, R.; Ulrich, H.; Kihara, A. H. Interplay Between Exosomes, microRNAs and Toll-Like Receptors in Brain Disorders. Mol. Neurobiol. 2016, 53 (3), 2016-2028.

[202] Buzas, E. I.; György, B.; Nagy, G.; Falus, A.; Gay, S. Emerging Role of Extracellular Vesicles in Inflammatory Diseases. Nat. Rev. Rheumatol. 2014, 10 (6), 356-364.

[203] Feiler, M. S.; Strobel, B.; Freischmidt, A.; Helferich, A. M.; Kappel, J.; Brewer, B. M.; Li, D.; Thal, D. R.; Walther, P.; Ludolph, A. C.; Danzer, K. M.; Weishaupt, J. H. TDP-43 Is Intercellularly Transmitted across Axon Terminals. J. Cell Biol. 2015, 211 (4), 897-911.

[204] Gomes, C.; Keller, S.; Altevogt, P.; Costa, J. Evidence for Secretion of Cu,Zn Superoxide Dismutase via Exosomes from a Cell Model of Amyotrophic Lateral Sclerosis. Neurosci Lett 2007, 428 (1), 43-46.

[205] Basso, M.; Pozzi, S.; Tortarolo, M.; Fiordaliso, F.; Bisighini, C.; Pasetto, L.; Spaltro, G.; Lidonnici, D.; Gensano, F.; Battaglia, E.; Bendotti, C.; Bonetto, V. Mutant Copper-Zinc Superoxide Dismutase (SOD1) Induces Protein Secretion Pathway Alterations and Exosome Release in Astrocytes: Implications for Disease Spreading and Motor Neuron Pathology in Amyotrophic Lateral Sclerosis. J. Biol. Chem. 2013, 288 (22), 15699-15711.

[206] Gosselin, R.-D.; Meylan, P.; Decosterd, I. Extracellular Microvesicles from Astrocytes Contain Functional Glutamate Transporters: Regulation by Protein Kinase C and Cell Activation. Front. Cell. Neurosci. 2013, 7, 251.

[207] Goodall, E. F.; Heath, P. R.; Bandmann, O.; Kirby, J.; Shaw, P. J. Neuronal Dark Matter: The Emerging Role of microRNAs in Neurodegeneration. Front. Cell. Neurosci. 2013, 7, 178.

[208] Marcuzzo, S.; Bonanno, S.; Kapetis, D.; Barzago, C.; Cavalcante, P.; D’Alessandro, S.; Mantegazza, R.; Bernasconi, P. Up-Regulation of Neural and Cell Cycle-Related microRNAs in Brain of Amyotrophic Lateral Sclerosis Mice 
at Late Disease Stage. Mol. Brain 2015, 8, 5.

[209] Parisi, C.; Napoli, G.; Amadio, S.; Spalloni, A.; Apolloni, S.; Longone, P.; Volonté, C. MicroRNA-125b Regulates Microglia Activation and Motor Neuron Death in ALS. Cell Death Differ. 2016, 23 (3), 531-541.

[210] Takahashi, I.; Hama, Y.; Matsushima, M.; Hirotani, M.; Kano, T.; Hohzen, H.; Yabe, I.; Utsumi, J.; Sasaki, H. Identification of Plasma microRNAs as a Biomarker of Sporadic Amyotrophic Lateral Sclerosis. Mol. Brain 2015, 8 (1), 67.

[211] Wakabayashi, K.; Mori, F.; Kakita, A.; Takahashi, H.; Utsumi, J.; Sasaki, H. Analysis of microRNA from Archived Formalin-Fixed Paraffin-Embedded Specimens of Amyotrophic Lateral Sclerosis. Acta Neuropathol. Commun. 2014, 2, 173.

[212] Campos-Melo, D.; Droppelmann, C. A.; He, Z.; Volkening, K.; Strong, M. J. Altered microRNA Expression Profile in Amyotrophic Lateral Sclerosis: A Role in the Regulation of NFL mRNA Levels. Mol. Brain 2013, 6, 26.

[213] Toivonen, J. M.; Manzano, R.; Oliván, S.; Zaragoza, P.; García-Redondo, A.; Osta, R. MicroRNA-206: A Potential Circulating Biomarker Candidate for Amyotrophic Lateral Sclerosis. PLoS One 2014, 9 (2), e89065.

[214] Benigni, M.; Ricci, C.; Jones, A. R.; Giannini, F.; Al-Chalabi, A.; Battistini, S. Identification of miRNAs as Potential Biomarkers in Cerebrospinal Fluid from Amyotrophic Lateral Sclerosis Patients. Neuromolecular Med. 2016.

[215] Burgos, K.; Malenica, I.; Metpally, R.; Courtright, A.; Rakela, B.; Beach, T.; Shill, H.; Adler, C.; Sabbagh, M.; Villa, S.; Tembe, W.; Craig, D.; Van KeurenJensen, K. Profiles of Extracellular miRNA in Cerebrospinal Fluid and Serum from Patients with Alzheimer's and Parkinson's Diseases Correlate with Disease Status and Features of Pathology. PLoS One 2014, 9 (5), e94839.

[216] Freischmidt, A.; Müller, K.; Ludolph, A. C.; Weishaupt, J. H. Systemic Dysregulation of TDP-43 Binding microRNAs in Amyotrophic Lateral Sclerosis. Acta Neuropathol. Commun. 2013, 1, 42.

[217] Freischmidt, A.; Müller, K.; Zondler, L.; Weydt, P.; Volk, A. E.; Božič, A. L.; Walter, M.; Bonin, M.; Mayer, B.; von Arnim, C. A. F.; Otto, M.; Dieterich, C.; Holzmann, K.; Andersen, P. M.; Ludolph, A. C.; Danzer, K. M.; Weishaupt, J. H. Serum microRNAs in Patients with Genetic Amyotrophic Lateral Sclerosis and Pre-Manifest Mutation Carriers. Brain 2014, 137 (Pt 11), 2938-2950.

[218] Freischmidt, A.; Müller, K.; Zondler, L.; Weydt, P.; Mayer, B.; von Arnim, C.; Hübers, A.; Dorst, J.; Otto, M.; Holzmann, K.; Ludolph, A.; Danzer, K.; Weishaupt, J. Serum microRNAs in Sporadic Amyotrophic Lateral Sclerosis. Neurobiol Aging 2015, 36 (9), 2660.e15-20.

[219] Koval, E. D.; Shaner, C.; Zhang, P.; du Maine, X.; Fischer, K.; Tay, J.; Chau, B. N.; Wu, G. F.; Miller, T. M. Method for Widespread microRNA-155 Inhibition Prolongs Survival in ALS-Model Mice. Hum. Mol. Genet. 2013, 22 (20), 41274135.

[220] Parisi, C.; Arisi, I.; D’Ambrosi, N.; Storti, A. E.; Brandi, R.; D’Onofrio, M.; Volonté, C. Dysregulated microRNAs in Amyotrophic Lateral Sclerosis Microglia Modulate Genes Linked to Neuroinflammation. Cell Death Dis. 2013, 
4, e959.

[221] Agosta, F.; Dalla Libera, D.; Spinelli, E. G.; Finardi, A.; Canu, E.; Bergami, A.; Bocchio Chiavetto, L.; Baronio, M.; Comi, G.; Martino, G.; Matteoli, M.; Magnani, G.; Verderio, C.; Furlan, R. Myeloid Microvesicles in Cerebrospinal Fluid Are Associated with Myelin Damage and Neuronal Loss in Mild Cognitive Impairment and Alzheimer Disease. Ann. Neurol. 2014, 76 (6), 813-825.

[222] Verderio, C.; Muzio, L.; Turola, E.; Bergami, A.; Novellino, L.; Ruffini, F.; Riganti, L.; Corradini, I.; Francolini, M.; Garzetti, L.; Maiorino, C.; Servida, F.; Vercelli, A.; Rocca, M.; Dalla Libera, D.; Martinelli, V.; Comi, G.; Martino, G.; Matteoli, M.; Furlan, R. Myeloid Microvesicles Are a Marker and Therapeutic Target for Neuroinflammation. Ann. Neurol. 2012, 72 (4), 610-624.

[223] Chang, C.; Lang, H.; Geng, N.; Wang, J.; Li, N.; Wang, X. Exosomes of BV-2 Cells Induced by Alpha-Synuclein: Important Mediator of Neurodegeneration in PD. Neurosci Lett 2013, 548, 190-195.

[224] Joshi, P.; Turola, E.; Ruiz, A.; Bergami, A.; Libera, D. D.; Benussi, L.; Giussani, P.; Magnani, G.; Comi, G.; Legname, G.; Ghidoni, R.; Furlan, R.; Matteoli, M.; Verderio, C. Microglia Convert Aggregated Amyloid- $\beta$ into Neurotoxic Forms through the Shedding of Microvesicles. Cell Death Differ. 2014, 21 (4), 582-593.

[225] Pusic, A. D.; Kraig, R. P. Phasic Treatment with Interferon Gamma Stimulates Release of Exosomes That Protect Against Spreading Depression. J. Interferon Cytokine Res. 2015, 35 (10), 795-807.

[226] Garzetti, L.; Menon, R.; Finardi, A.; Bergami, A.; Sica, A.; Martino, G.; Comi, G.; Verderio, C.; Farina, C.; Furlan, R. Activated Macrophages Release Microvesicles Containing Polarized M1 or M2 mRNAs. J. Leukoc. Biol. 2013.

[227] Bernimoulin, M.; Waters, E. K.; Foy, M.; Steele, B. M.; Sullivan, M.; Falet, H.; Walsh, M. T.; Barteneva, N.; Geng, J.-G.; Hartwig, J. H.; Maguire, P. B.; Wagner, D. D. Differential Stimulation of Monocytic Cells Results in Distinct Populations of Microparticles. J. Thromb. Haemost. 2009, 7 (6), 1019-1028.

[228] Cheah, B. C.; Vucic, S.; Krishnan, A. V; Kiernan, M. C. Riluzole, Neuroprotection and Amyotrophic Lateral Sclerosis. Curr. Med. Chem. 2010, 17 (18), 1942-199.

[229] Gordon, P. H.; Meininger, V. How Can We Improve Clinical Trials in Amyotrophic Lateral Sclerosis? Nat. Rev. Neurol. 2011, 7 (11), 650-654.

[230] Mitsumoto, H.; Brooks, B.; Silani, V. Clinical Trials in Amyotrophic Lateral Sclerosis: Why so Many Negative Trials and How Can Trials Be Improved? Lancet Neurol. 2014, 13 (11), 1127-1138.

[231] Blasco, H.; Patin, F.; Andres, C. R.; Corcia, P.; Gordon, P. H. Amyotrophic Lateral Sclerosis, 2016: Existing Therapies and the Ongoing Search for Neuroprotection. Expert Opin. Pharmacother. 2016, 17 (12), 1669-1682.

[232] Volpe, C. M. O.; Nogueira-Machado, J. A. Is Innate Immunity and Inflammasomes Involved in Pathogenesis of Amyotrophic Lateral Sclerosis (ALS)? Recent Pat. Endocr. Metab. Immune Drug Discov. 2015, 9 (1), 40-45. 


\section{FIGURE LEGENDS}

Figure 1: ALS viewed as a multifactorial disease with diverse clinical presentations and neurodegeneration patterns. a) Overlapping of ALS clinical manifestations and diverse pathologies depends on the main mutated genes, except for $\mathrm{C} 9$ orf 72 , common to all diseases. b) Drawing represents ALS genetics as a continuum spectrum, ranging from a monogenic inherited disease (fALS) to idiopathic sALS, and with a decreasing gene penetrance. In this model, misfolded TDP-43 protein aggregation and neuroinflammation are the only pathological mechanisms common to all ALS phenotypes.

Figure 2: Cellular processes involving altered responses of dysfunctional glia in ALS. Misfolded protein aggregates (MPA) induce motor neuron and astrocyte suffering and the neuronal release of glial activation signals. Reactive microglia mediate different pro-inflammatory and neuroprotective processes in coordination with astrocytes and requires increased energy consumption. Extracellular MPA also activates microglial phagocytic activity to remove aggregates, which results in microglial dysfunction that directly participates in neurodegeneration. Gene polymorphisms inducing decreased C9orf72 activity favor misfolded protein aggregation and microglial dysfunction (see text for details).

Figure 3: Signaling systems involved in the ALS neuron-microglia-astrocyte crosstalk. Astrocytes and microglia modulate neuronal activity by sensing neurotransmitter release. Also, microglia have receptors to molecules released by astrocytes and viceversa. In ALS, reactive microglia and astrocytes mediate different neuroprotective (green arrows) and cytotoxic processes (red arrows) according to a diversity of signals 
from the injured motor neurons. This glial activation mobilizes the immune system, also proposed to trigger motor plaque injury and neurodegeneration. 5-HT, serotonin; Ach, acetylcholine; Ado, adenosine; BDNF, Brain-derived neurotrophic factor; bFGF, fibroblast growth factor-b; EAAT-1, excitatory amino acid transporter-1; GABA, $\gamma$ aminobutyric acid; GDNF, glial cell-derived neurotrophic factor; Glu, glutamate; GSH, glutathione; IFN $\gamma$, interferon gamma; IGF-1, insulin-like growth factor-1; IL-1 $\beta, 4,5,6$, 10, interleukins 1beta, 4, 5, 6, 10; MVs, microvesicles; NMJ, neuromuscular junction; NO, nitric oxide; NT3, neurotrophin 3; ROS, reactive oxygen species; Tau, taurine; TGF $\beta$, transforming growth factor beta, TNF- $\alpha$, tumor necrosis factor alpha; VEGF, vascular endothelial growth factor; VIP, vasoactive intestinal peptide. 
Table 1: Major genes associated with ALS

\begin{tabular}{|c|c|c|c|c|}
\hline Gene & Protein name & Protein description and function. & ALS pathophysiology & ALS association \\
\hline SOD1 & $\begin{array}{l}\mathrm{Cu} / \mathrm{Zn} \text { Superoxide } \\
\text { dismutase } 1, \text { soluble }\end{array}$ & $\begin{array}{l}\text { Soluble cytoplasmic protein, acting as a homodimer to } \\
\text { convert endogenous but harmful superoxide radicals to } \\
\text { molecular oxygen and hydrogen peroxide. }\end{array}$ & Aggregate formation & Cause \\
\hline FUS & Fused in sarcoma & $\begin{array}{l}\text { Multifunctional protein component of the heterogeneous } \\
\text { nuclear ribonucleoprotein (hnRNP) complex. The hnRNP } \\
\text { complex is involved in pre-mRNA splicing and the export } \\
\text { of fully processed mRNA to the cytoplasm. }\end{array}$ & $\begin{array}{l}\text { Altered function and } \\
\text { Aggregate formation. }\end{array}$ & Cause \\
\hline TARDBP & $\begin{array}{l}\text { Transactive response } \\
\text { DNA-binding protein } 43\end{array}$ & $\begin{array}{l}\text { Transcriptional repressor that binds to chromosomally } \\
\text { integrated transactive response DNA and represses HIV-1 } \\
\text { transcription. It also regulates alternate splicing of the } \\
\text { CFTR gene. }\end{array}$ & $\begin{array}{l}\text { TARDBP over-expression } \\
\text { leads to deregulation of ER- } \\
\text { mitochondria interactions } \\
\text { through VAPB and PTPIP51. } \\
\text { Aggregate formation }\end{array}$ & Cause \\
\hline UBQLN2 & Ubiquilin 2 & $\begin{array}{l}\text { Ubiquitin-like protein that physically associates with both } \\
\text { proteasomes and ubiquitin ligases; and thus, are thought } \\
\text { to functionally link the ubiquitination machinery to the } \\
\text { proteasome to modify protein degradation. }\end{array}$ & $\begin{array}{l}\text { Protein aggregates activate, } \\
\text { chronic ER stress. }\end{array}$ & $\begin{array}{l}\text { Cause / } \\
\text { Increased risk }\end{array}$ \\
\hline SETX & Senataxin & $\begin{array}{l}\text { This protein contains a DNA/RNA helicase domain. This } \\
\text { suggests that it may be involved in both DNA and RNA } \\
\text { processing. }\end{array}$ & $\begin{array}{l}\text { hnRNP complex } \\
\text { deregulation? }\end{array}$ & $\begin{array}{l}\text { Cause / } \\
\text { increased risk }\end{array}$ \\
\hline SPG11 & $\begin{array}{l}\text { Spastic paraplegia } 11 \\
\text { (autosomal recessive). } \\
\text { Spatacsin }\end{array}$ & $\begin{array}{l}\text { This protein is needed for the recycling of lysosomes from } \\
\text { autophagic lysosome reformation. }\end{array}$ & $\begin{array}{l}\text { ER stress leading to } \\
\text { neurodegeneration }\end{array}$ & Increased risk \\
\hline VAPB & $\begin{array}{l}\text { VAMP (vesicle- } \\
\text { associated membrane } \\
\text { protein)-associated } \\
\text { protein B and C }\end{array}$ & $\begin{array}{l}\text { Membrane protein found in plasmalemmal and } \\
\text { intracellular vesicle membranes. It is found as a } \\
\text { homodimer and as a heterodimer with VAPA. It can also } \\
\text { interact with VAMP1 and VAMP2 and may be involved } \\
\text { in vesicle trafficking. }\end{array}$ & $\begin{array}{l}\text { VAPB cytoplasmic } \\
\text { aggregates triggers calcium } \\
\text { dependent aberrant ER and } \\
\text { Golgi structures and function }\end{array}$ & Increased risk \\
\hline ATXN2 & Ataxin 2 & $\begin{array}{l}\text { Protein primarily localized to the Golgi apparatus with } \\
\text { unknown function. }\end{array}$ & $\begin{array}{l}\text { Associate with TDP-43. ER } \\
\text { stress leading to } \\
\text { neurodegeneration }\end{array}$ & Increased risk \\
\hline TBK1 & TANK binding kinase 1 & 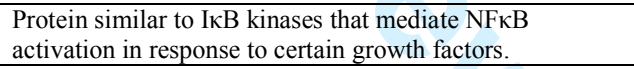 & $\begin{array}{l}\text { Control of } \\
\text { neuroinflammation? }\end{array}$ & Increased risk \\
\hline UNC13A & $\begin{array}{l}\text { unc-13 homolog A }(\mathrm{C} . \\
\text { elegans) }\end{array}$ & $\begin{array}{l}\text { Member of the UNC13 family. These proteins bind to } \\
\text { phorbol esters and diacylglycerol and play important roles } \\
\text { in neurotransmitter release at synapses. }\end{array}$ & $\begin{array}{l}\text { Excitotoxicity and glutamate- } \\
\text { induced neurodegeneration. }\end{array}$ & $\begin{array}{l}\text { Decreased } \\
\text { survival }\end{array}$ \\
\hline CX3CR1 & $\begin{array}{l}\mathrm{C}-\mathrm{X} 3-\mathrm{C} \text { motif } \\
\text { chemokine receptor } 1\end{array}$ & $\begin{array}{l}\text { Receptor for fractalkine, a transmembrane protein and } \\
\text { chemokine involved in the adhesion and migration of } \\
\text { leukocytes. In the CNS is expressed by microglia and } \\
\text { mediates neuron-microglia interactions. }\end{array}$ & $\begin{array}{l}\text { Control of } \\
\text { neuroinflammation }\end{array}$ & $\begin{array}{l}\text { Decreased } \\
\text { survival }\end{array}$ \\
\hline KIFAP3 & $\begin{array}{l}\text { kinesin associated } \\
\text { protein } 3\end{array}$ & $\begin{array}{l}\text { Unknown. It interacts with human chromosome- } \\
\text { associated polypeptide (HCAP) and KIF3A/B, a kinesin } \\
\text { superfamily protein in the nucleus. It is proposed to play a } \\
\text { role in the interaction of chromosomes with ATPase } \\
\text { motor proteins. }\end{array}$ & $\begin{array}{l}\text { Vesicle and organelle } \\
\text { trafficking? }\end{array}$ & $\begin{array}{l}\text { Decreased } \\
\text { survival }\end{array}$ \\
\hline EPHA4 & EPH receptor A4 & $\begin{array}{l}\text { Ephrin receptor subfamily of receptors with protein- } \\
\text { tyrosine kinase activity. It is implicated in developmental } \\
\text { events, particularly in the nervous system. }\end{array}$ & Neuroprotective actions? & $\begin{array}{l}\text { Decreased } \\
\text { survival }\end{array}$ \\
\hline SLC11A2 & $\begin{array}{l}\text { solute carrier family } 11 \\
\text { member } 2\end{array}$ & $\begin{array}{l}\text { Also known as DMT1, this protein transports divalent } \\
\text { metals and is involved in iron absorption. Mutations in } \\
\text { this gene are associated with hypochromic microcytic } \\
\text { anemia with iron overload. }\end{array}$ & $\begin{array}{l}\text { Altered metal homeostasis. It } \\
\text { may form aggregates with } \\
\text { SOD1 }\end{array}$ & $\begin{array}{l}\text { Decreased } \\
\text { survival }\end{array}$ \\
\hline
\end{tabular}

Table shows examples of genes in which polymorphisms cause, increase the risk or modify progression rate of ALS. Not everyone carrying a disease-related mutation in these genes develops ALS, which suggests that other factors are needed to cause disease. 


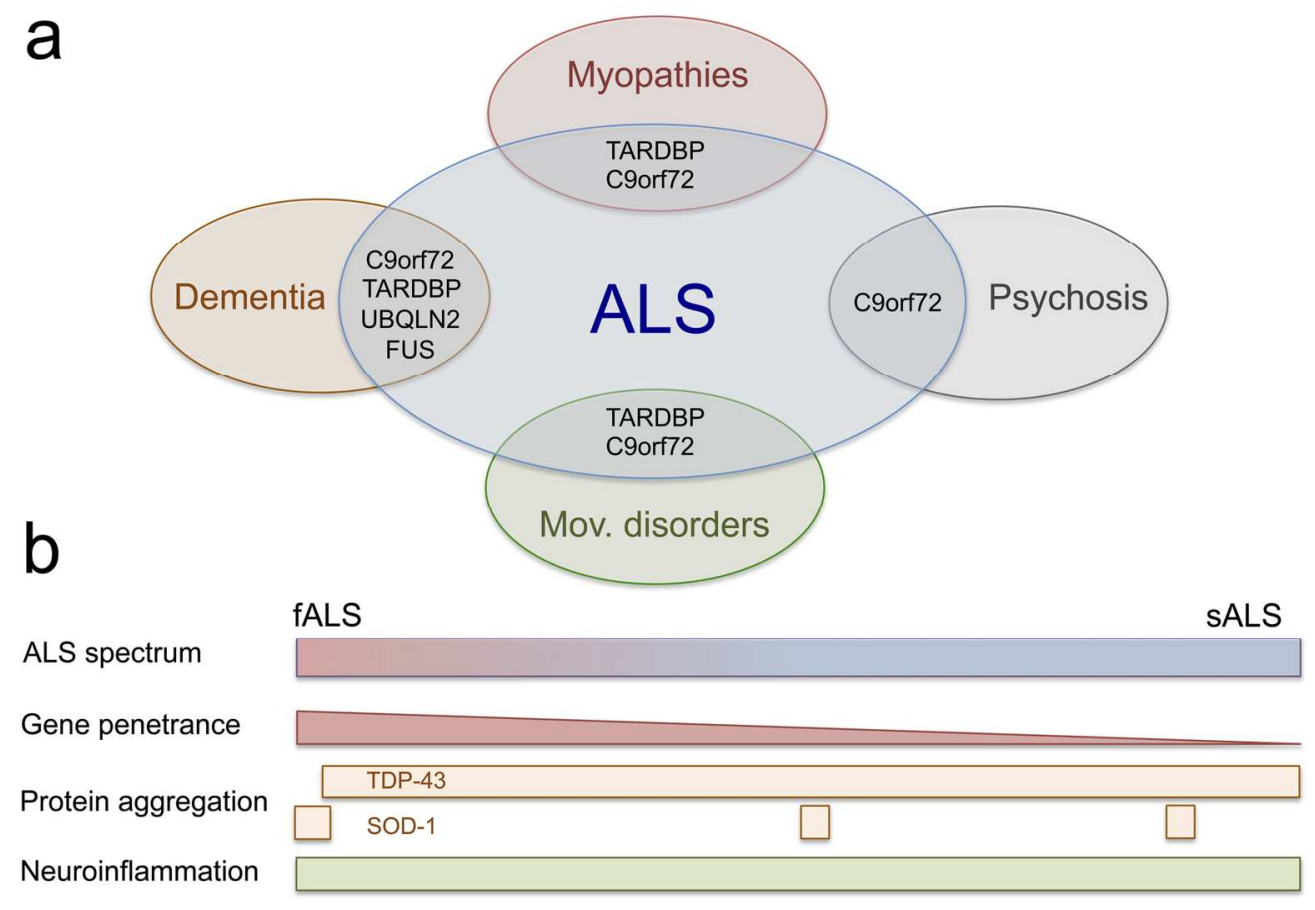

Figure 1

Figure 1: ALS viewed as a mult $154 \times 109 \mathrm{~mm}(300 \times 300 \mathrm{DPI})$ 


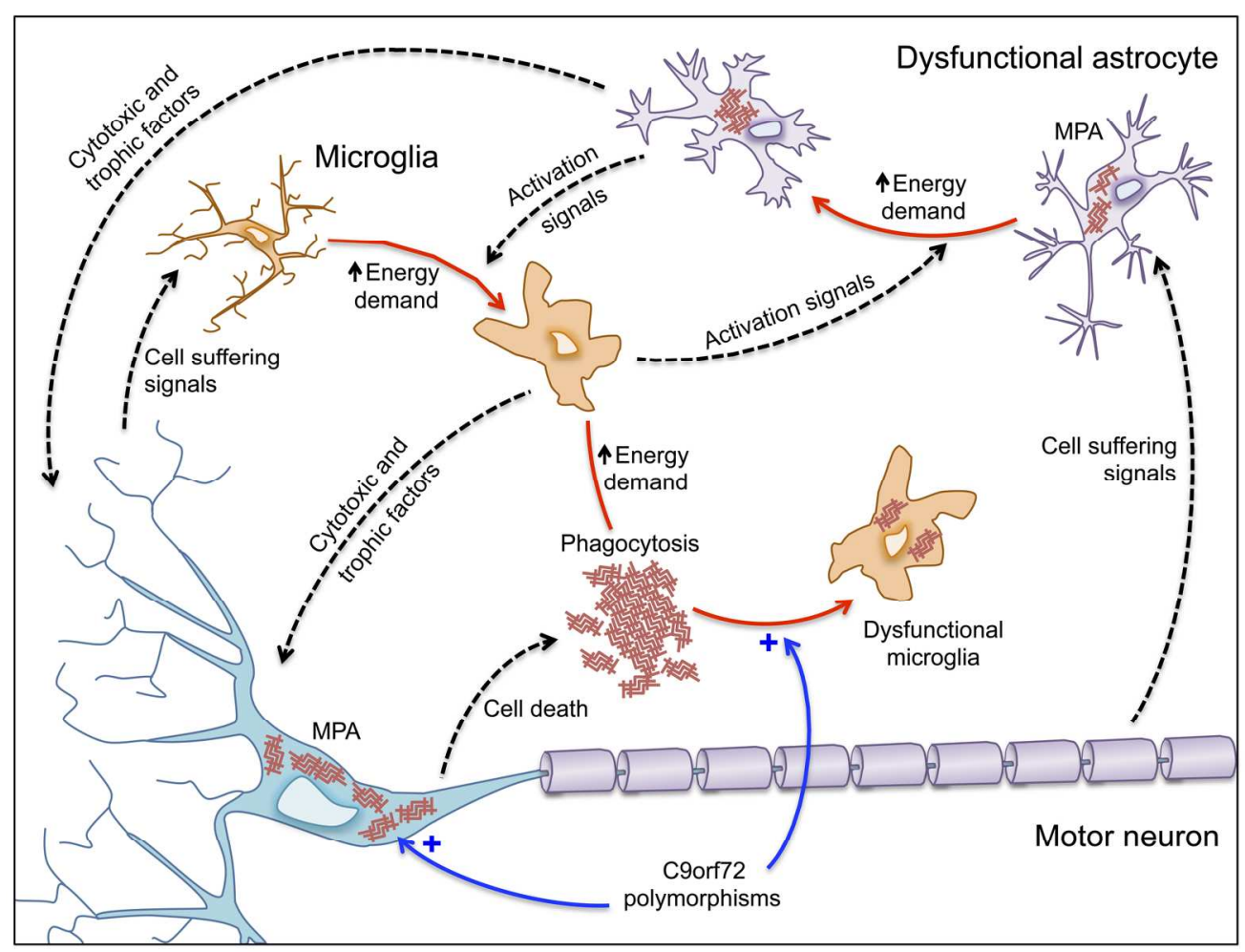

Figure 2: Cellular processes involving altered responses of dysfunctional glia in ALS Figure 2

$172 \times 133 \mathrm{~mm}(300 \times 300$ DPI $)$ 


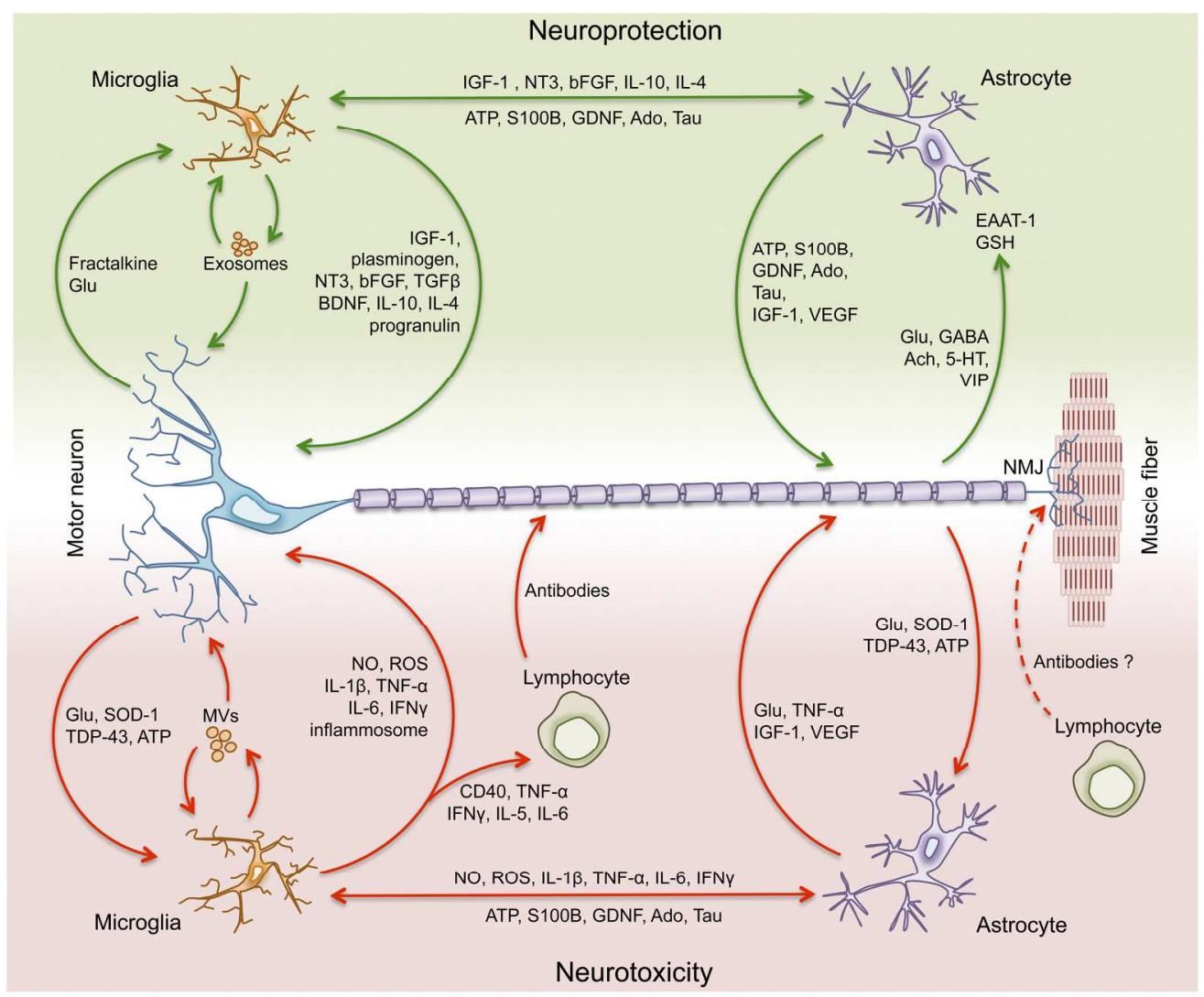

Figure 3: Signaling systems involved in the ALS neuron-microglia-astrocyte crosstalk Figure 3 